\title{
Entrepreneur fund-seeking: toward a theory of funding fit in the era of equity crowdfunding
}

\author{
Regan Stevenson (1) - Sean R. McMahon • Chaim \\ Letwin • Michael P. Ciuchta
}

Accepted: 15 April 2021 / Published online: 12 May 2021

(C) The Author(s), under exclusive licence to Springer Science+Business Media, LLC, part of Springer Nature 2021

\begin{abstract}
Why do entrepreneurs prefer to seek one equity form of funding over another? To address this question, we develop a contingency-based model of perceived funding fit that delineates several factors that influence strategic fund-seeking decisions by entrepreneurs. In prior research, entrepreneur fund-seeking has largely been explained using models that rely on rulebased approaches (e.g., the pecking order assumption) or value capture considerations. In contrast, we propose a dynamic contingency-based model that delineates several factors that influence entrepreneur perceptions of funding fit over and above transactional efficiency, including atypical value creation from the fundraising process itself and external stakeholder values. We inductively assess our model in the context of equity crowdfunding (ECF) and find that perceived funding
\end{abstract}

R. Stevenson $(\bowtie)$

Kelley School of Business, Indiana University, 1275 E 10th, St. Bloomington, IN 47405, USA

e-mail: rstev@indiana.edu

\section{S. R. McMahon}

Love School of Business, Elon University, 401 North O'Kelly

Ave., Elon, NC 27244, USA

e-mail: smcmahon2@elon.edu

\section{Letwin}

Sawyer Business School, Suffolk University, 73 Tremont, St.

Boston, MA 02108, USA

e-mail: cletwin@suffolk.edu

\section{P. Ciuchta}

Robert J. Manning School of Business, UMASS - Lowell, One University Ave., Lowell, MA 01854, USA

e-mail: michael_ciuchta@uml.edu fit can motivate some strategic fund-seekers to opt to pursue ECF, even when they have a reasonable opportunity to obtain other more established sources of funding such as angel or seed-stage venture capital. This indicates that ECF in several cases is not a funding mode of last resort as proposed in prior literature.

Plain English Summary Raising capital is a complex and dynamic process. Strategic entrepreneurs seek "funding fit" for their particular ventures leading some to opt for less established forms of funding such as equity crowdfunding for a variety of reasons beyond efficiency. Prior venture funding research has largely taken the view of the investor, emphasizing what entrepreneurs must do to win the favor of angel investors and other seed funders, and deeming equity crowdfunding (ECF) a funding mode of last resort for discouraged entrepreneurs. Inductively analyzing hundreds of regulatory filings, entrepreneur interviews, public information, and media pieces about ECF-funded firms, we find evidence that in several cases, strategic entrepreneurs may prefer to opt for ECF if they perceive it to be a better fit due to novel forms of nonfinancial value. We explain our findings by proposing an emergent contingency-based model of "funding fit."

JEL classifications $\mathrm{L} 26 \cdot \mathrm{M} 13$

Keywords Funding fit, · Equity crowdfunding, · Entrepreneurship, $\cdot$ Capital raising, $\cdot$ Venture investment $\cdot$ Venture finance $\cdot$ Value creation 


\section{Introduction}

Equity crowdfunding (ECF) is a novel and unique form of entrepreneurial finance that allows entrepreneurs to seek equity directly from distributed crowds of investors. Scholars note that the rapid rise of ECF could have farreaching implications for existing venture funding ecosystems (Cumming et al., 2019; Drover et al., 2017; Vismara, 2016), including the way in which entrepreneurs seek capital. Initial ECF research largely focused on investor decision-making, identifying several signals or other critical cues that influence how investors decide which ECF deals to fund (e.g., Ahlers et al., 2015; Bapna, 2019; Stevenson et al., 2019a). This approach, while valuable, de-emphasizes the antecedent role of the entrepreneur who must first decide which equity sources to seek and initiate the fund-seeking process itself. Indeed, these entrepreneurial decisions will have an effect on whether or not an equity deal will ultimately occur, hence the need to complement prior work on investor decision-making with research that focuses on entrepreneur fund-seeking.

At present, considerable debate remains about how entrepreneurs perceive ECF relative to other sources of equity funding. Some scholars contend that ECF largely functions as an option of "last resort" for entrepreneurs (Brown et al., 2018; Walthoff-Borm et al., 2018a), while others argue that obtaining ECF could be a preferred funding option (Cummings et al., 2020). Given the nascency of ECF, at present, we have an incomplete picture as to why some entrepreneurs might seek ECF over alternative forms of funding. Thus, we consider the following research question, when entrepreneurs decide to seek equity, what factors influence their decision to pursue ECF instead of other more established forms of equity? To answer this question, we first draw insights from recent research that has looked at antecedents of ECF fund-seeking (e.g., Blaseg et al., 2020; WalthoffBorm et al., 2018a). We then theoretically build upon this framework and inductively develop a contingency based model of perceived funding fit. Unlike rulebased or value capture models of fund-seeking, the theoretical model we develop emphasizes the expanded set of contingency factors (e.g., value creation considerations, social value considerations) at play when entrepreneurs consider alternative sources of equity funding. Our model also emphasizes active role that entrepreneur perceptions play in the modern fund-seeking process, as opposed to a rule-based economic calculus models that have dominated the literature in prior decades.

To develop and test our model, we conduct an inductive multiple-case research design, hand-coding more than 200 ECF artifacts (cumulatively 1436 pages) and direct interviews with US-based ECF fund-seekers and ECF funders. We build off prior ECF research conducted in regions where ECF is already well established (Brown et al., 2018; Cholakova and Clarysse, 2015; Cumming et al., 2019). Cummings et al. (2020, p. 907) identify, "there is still much to be learned, especially in the USA, where national equity crowdfunding campaigns have only been open to unaccredited investors since 2016." The US setting presents several opportunities to advance theory related to entrepreneurial fund-seeking because the USA has recently experienced one of the most high-profile legal pushes encouraging ECF and because it has significant structural and economic factors that should contribute to ECF's expansion.

Our research makes two primary contributions to the literature. First, we contribute to theory by putting forth a model of perceived funding fit, a contingency-based perspective which specifies that equity fund-seeking is a dynamic process in which entrepreneurs attempt to identify the funding mode that best fits their particular needs and circumstances at a given point in time. Much prior work looking at entrepreneur fund-seeking is derived from value capture frameworks (e.g., transaction cost economics; Williamson, 1988) or rule-based pecking orders (e.g., pecking order theory; Myers, 1984). These models of fund-seeking are ideal to explain fundseeking when decisions are largely based on calculable pecuniary cost differences between choices, or when choice sets and associated decision contexts are clearly definable. However, these rule-based models are less reliable in today's dynamic fundraising setting where many more discrete fundraising options exist (Bruton et al., 2015) and where entrepreneurs may prioritize novel contingency factors. We argue that rule-based models rather than "fit" models under-emphasize the active role that entrepreneur perception plays in the fund-seeking process. In contrast, the funding fit perspective brings to light salient non-pecuniary contingencies that entrepreneurs consider when fund-seeking, such as value creation from the fund-seeking process itself and shifting power dynamics. While we use ECF to develop our contingency model of funding fit, we believe it has applicability in other funding contexts as 
well (although additional contingency factors are likely to be in play beyond the ECF setting).

Second, we develop actionable propositions that specify why strategic fund-seekers might choose to pursue ECF instead of more well-established forms of equity. Initial work in this area contends that ECF is often a secondary or backup funding source, down the line in a pecking order fashion (Walthoff-Borm et al., 2018a). Yet, prior work also speculates that ECF's "unique characteristics might enable equity crowdfunding to reverse the pecking order" (Walthoff-Borm et al., 2018a, p. 514). However, what exactly those unique characteristics are and how they influence fund-seeker perceptions is not well understood. As one example, prior work identifies that over and above the financial value of an equity deal, entrepreneurs often covet strategic value (e.g., managerial expertise) from traditional investors (Baum and Silverman, 2004; Park and Steensma, 2012). In ECF, useful managerial expertise embedded within a dispersed crowd of funders is less readily available and harder to extract. However, our data reveals that entrepreneurs are still drawn to ECF to gain access to other complementary strategic resources, such as demand-side resources like market validation information and other, complementary resources that are more likely to be part of dispersed crowd-based transactions. Overall, we explain how access to these unique forms of nonfinancial value and other value considerations influence some entrepreneurs to seek ECF over other forms of equity.

\section{Theory and background}

\subsection{Prior research on equity crowdfunding}

ECF is an emerging form of fundraising that became legal in the USA on May 16, 2016. Prior to that time, raising equity capital from non-accredited investors over the internet was a prohibited practice (SEC, 2016a). While still sparse, there is a growing literature stream focused on ECF. Ahlers et al. (2015) used signaling theory with an Australian sample and found that human capital positively impacted funder decisions. Extending this perspective, Stevenson et al. (2019a) found that, over and above signal quality, crowd cues (indicators from the crowd about an investment opportunity) whether accurate or not, also have a strong influence on crowdfunder decisions. Also considering the role of investors in selecting deals, Cholakova and Clarysse (2015) used self-determination theory and found ECF investors were primarily motivated by financial incentives, whereas rewards-based crowdfunders were more likely to be motivated by non-financial motives.

Indicating a need to extend beyond investor decisionmaking models, Belleflamme et al. (2014) noted future work should consider the motivations and reasons that influence some entrepreneurs to pursue crowdfunding mechanisms. Toward this goal, Brown et al. (2018) explored the motivations of improvisational fundseekers using the bricolage perspective (Baker and Nelson, 2005). These authors found that there was strong demand for ECF among "discouraged borrowers" (Brown et al., 2018, p. 1). Similarly, Blaseg et al. (2020) found evidence that prior connections to distressed banks pushed entrepreneurs to use ECF. They also found some initial evidence, albeit less robust, that entrepreneurs who can access other forms of equity are less likely to use ECF in the German context. In terms of why some might avoid ECF, Gleasure (2015), using a sample of Irish entrepreneurs, found that those that avoided crowdfunding did so out of a fear of failure. These findings indicate why some low-quality entrepreneurs (see Blaseg et al., 2020) might seek ECF out of necessity but leave open the question as to the motivations of higher quality firms.

Beyond motivations, some research indicates that there may be some longer-term drawbacks to ECF. Recent findings indicate that ECF firms in Germany and the UK have much higher failure rates (Blaseg et al., 2020; Walthoff-Borm et al., 2018b). Estrin et al. (2018) investigated ECF financial flows to entrepreneurs in the UK. These authors found that ECF investments "have probably been largely incremental to traditional sources of early stage entrepreneurial finance" (Estrin et al., 2018, p. 425). They do, however, note that ECF has the potential to allow entrepreneurs to turn existing customers into investors, and that savvy entrepreneurs might consider ECF as a mechanism upon which they can create "momentum and buzz" for their companies. Their sample identifies several entrepreneurs who made a "conscious choice" to either engage or not engage with ECF. This indicates that, at least for some entrepreneurs, ECF might be considered a preferred choice. We develop this concept further in our study and unpack the underlying reasons why some entrepreneurs have a choice (strategic fund-seekers) and others do not (necessity fund-seekers) in deciding to use ECF. 
Given the uniqueness and recent emergence of ECF, many scholars have called for additional research to unpack the underlying motivations that might influence ECF fund-seeking. Walthoff-Borm et al. (2018a) call for more work on ECF, advising scholars to investigate the demand for equity crowdfunding by entrepreneurs, noting there is a possibility that ECF could revert or distort entrepreneurial fund-seeking preferences (see also Bellavitis et al., 2017). Cummings et al. (2020) echo these calls for future research to consider the circumstances in which equity crowdfunding might become an entrepreneur's preferred funding option, as opposed to a secondary option. In line with these calls for more research on ECF fund-seeker choices and preferences, we extend this work by exploring the conditions under which ECF will be preferred to other equity sources by US-based firms. Distinct from prior work, we focus on unpacking the motivations and preferences of highgrowth "strategic" fund-seekers.

\subsection{Seeking equity funding}

When entrepreneurs obtain traditional equity funding, prior research demonstrates that entrepreneurs benefit by capturing extra-financial value from financiers including management experience and business knowledge (Baum and Silverman, 2004; Ciuchta et al., 2018; Sapienza et al., 1996). Access to this complementary value from angels and VCs, in turn, improves new venture performance (Fitza et al., 2009; Hellmann and Puri, 2002; Sorensen, 2007). However, raising equity capital from traditional sources is onerous for entrepreneurs. Entrepreneurs spend significant time, money, and effort in order to search for, solicit, and secure funding (Gompers and Lerner, 2004; Zott and Huy, 2007). To form initial relationships with investors, entrepreneurs rely on their human capital and network ties when a proven track record is lacking (Hallen, 2008). Thus, inexperienced entrepreneurs are often severely constrained in their funding options. Once investors are identified by entrepreneurs, bilateral negotiations between entrepreneurs and investors ensue. This process tends to be adversarial (Zacharakis et al., 2010), usually involving costly attorneys to review and revise contracts over multiple rounds of communication (Klonowski, 2007). Moreover, equity deals often involve complex terms (e.g., liquidation preferences, anti-dilution, right of first refusal) aimed at reducing agency hazards for funders (Koss, 2007) by ensuring strategic control over entrepreneurs (Florin, 2005).

In the era prior to the introduction of ECF, research suggests that entrepreneurs often had limited power compared to their equity investor counterparts when negotiating and contracting funding deals (Hsu, 2004, 2007). Wasserman (2008, p. 3) states, "in order to attract investors and executives, entrepreneurs have to give up control over most decision making." Given these structural preferences by traditional funders, founder status rarely confers structural authority by the time a firm reaches the IPO stage (Nelson, 2003). Moreover, traditional angel and VC contracts may also include terms that allow the investor to oust founders from their firms well before the IPO stage. Wasserman (2008) found this to be a common occurrence in VC deals. There are many practical examples of board control issues by traditional early stage funders in the literature, including practices to ratchet down ownership after the deal closes (Koss, 2007), attempts to subsume strategic control (Bartlett, 1999), or expropriation of intellectual property.

2.3 Funding fit from the perspective of the fund-seeker

Although obtaining funding is a critical milestone for new ventures (Drover et al., 2017), the process is time consuming, and the act of fund-seeking diverts critical attention away from actually running the business (Van Osnabrugge, 2000). Given this, it is reasonable to expect that fund-seeking entrepreneurs will prefer to seek funding types that are costeffective and timely (cf. Brown et al., 2018). In addition, entrepreneurs also covet extra-financial value that can be captured from investors after the funding transaction occurs (Busenitz et al., 2005; Fitza et al., 2009; Park and Steensma, 2012). Yet, entrepreneurs often face a trade-off because the most efficient and cost-effective funding mode may not necessarily be congruent with the funding mode that provides the extra-financial value that they may covet. Each entrepreneur must therefore assess his or her own funding and strategic needs when considering which funding mode to pursue. We anticipate that entrepreneurs spend time and effort attempting to determine the funding mode that provides the best fit for them, given their particular needs and circumstances at a given point in time. We refer to this as perceived funding fit. For clarity, we define this construct as fund-seeker perceptions about the suitability 
of funding types for his or her own unique venture at its current stage of development. ${ }^{1}$

The nature of entrepreneurship dictates that entrepreneurs make decisions using speculative and imperfect information about funding modes, their own firms, and the environment (Kirzner, 1997; Mises, 1949). Moreover, although entrepreneurs attempt to maximize value (Casson, 1982), entrepreneurs' decisions are not solely a function of a "mechanical quest" for efficiency (Cyert and March, 1963). Due to the closed nature of traditional funding settings, entrepreneurs face difficulties in accurately evaluating the quality of the potential benefits that they might receive from a traditional equity partner (Hallen and Pahnke, 2016) and idiosyncratic perceptions play a vital role in strategic choices (Camerer et al., 2004; Powell et al., 2011). Thus, it is important to stress that funding fit is perceptual, residing in the mind of the entrepreneur.

Despite the perceptual differences described above, we expect that achieving funding fit will be highly salient for most fund-seeking entrepreneurs, much in the same way that product-market fit is highly salient for entrepreneurs who are introducing new products (cf. Shankar and Shepherd, 2018). To achieve product-market fit, entrepreneurs attempt to learn about the intentions of different customer groups and identify the particular customer archetypes that best fit with their particular business offering at their given stage of venture development (Blank, 2013; York and Danes, 2014). Similarly, we expect that entrepreneurs seek to achieve funding fit by identifying particular resource providers that they perceive to be the best fit (in terms of efficiencies and extra-financial value) for their particular ventures at a given development stage. Given that we are interested in the antecedents of perceived funding fit from the perspective of entrepreneurs, and given that ECF is an emergent phenomenon, we elected to engage in an inductive study, which we describe in detail in the next section.

\section{Methods}

We investigate the perceptions that underlie ECF fundseeking. We particularly focus on understanding why

\footnotetext{
${ }^{1}$ We note that the conceptual model of perceived funding fit developed in this research describes motivations behind the entrepreneur's fund seeking decisions but does not make claims regarding the longterm objective optimality of these fund-seeking perceptions or decisions.
}

some entrepreneurs pursue ECF over other forms of equity that they could otherwise obtain. We use an inductive multiple-case research design to explore this research question. This methodology inducts theory through systematic case comparison and allows for detailed exploration of novel phenomena (Eisenhardt, 1989). Focused case studies conducted in novel or emerging contexts have high potential to lead to valuable theoretical insights, while also providing a framework for future empirical work (e.g., Barley, 1986; Haveman and Baum, 1997; Pratt, 2000; Williams and Shepherd, 2016).

\subsection{Case selection}

Recall, ECF is a novel funding mode that became legal in the US on May 16, 2016. We initiated our study and selected our cases shortly after this time in mid-2016. At the time of the study, the leading portal represented $78 \%$ of the total US ECF live activity. Given the massive market share that this one portal had, we made the decision to focus our subsequent data collections on cases from within this portal to increase comparability of cases. At the time of our study, 54 companies had initiated an ECF raise on this portal, but 40 of these campaigns had not yet concluded. To avoid partial or incomplete data that would have emerged from selecting cases that were in the middle of a fund-raising round, we selected all 14 firms that had completed their ECF round as our cases. At the time we initiated our study, this sample represented the entire population of firms that had completed a round of funding on the market leading ECF portal in the USA.

The companies in our sample were operating in a number of distinct industries, from the beverage industry to biotech. On average, they had been in business for 3 years and had 6.4 employees. In terms of financial position, the companies had average cash reserves of $\$ 189,417$ and pre-funding assets of $\$ 742,356$. During their current equity funding round, these companies were seeking an average of $\$ 741,428$. This is comparable to the average US-based angel funding round $(\$ 345,390$; Sohl, 2016) and US-based seed-stage VC funding round $(\$ 833,077){ }^{2}$ The companies had premoney valuations between $\$ 2 \mathrm{M}$ to $\$ 100 \mathrm{M}$, whereas

\footnotetext{
${ }^{2}$ To obtain the comparable seed-stage VC figure, we analyzed data compiled by PWC (2017). We calculated the average seed-stage VC deal across 7973 seed-stage VC deals from Jan 1, 2005 to Dec 31, 2015.
} 
industry data indicates that average angel valuation was \$2.32 M (Sohl, 2016) and the average seed-stage VC valuation was $\$ 8 \mathrm{M}$ (PitchBook Data , 2016) for a similar time period. We present additional details about each company using pseudonyms in Table 1 .

\subsection{Data collection and sources}

The data sources used in this study include personal interviews with entrepreneurs and funders, ECF crowdfunding campaigns, ECF portal filings, SEC filings, pitch videos, websites, press releases, investorentrepreneur question and answer transcripts, and related unobtrusive archival documents that were publicly available. We hand-collected and coded more than 200 artifacts, cumulatively 1436 pages, that directly pertained to the venture cases. Our qualitative data collection approach combines source interviews with unobtrusive archival qualitative data to develop a multi-source 360 -view of the overall phenomenon. Using unobtrusive archival qualitative data to supplement researcher-initiated interviews is an increasingly common approach in qualitative research (e.g., David et al., 2013; Fisher et al., 2020; Waldron et al., 2015). We describe each data source below and provide additional detail in Table 2.

ECF crowdfunding campaigns and pitch videos Each venture posted and maintained a campaign webpage on the ECF portal throughout the duration of their fundraising efforts. On this webpage, entrepreneurs make their formal pitch to potential investors by providing detailed information about themselves and their company. Information includes business plans, video pitches, entrepreneur experiential biographies, founding team profiles, company history, prior funding, capitalization tables, intellectual property, competitive analysis, distribution strategies, timelines and milestones, customer testimonials, investor endorsements, exit strategies, and frequently asked questions. We reviewed all of the text and graphics on these pages, cumulatively 472 total pages.

Entrepreneur-investor question and answer portals We also analyzed all the documented interactions between entrepreneurs and their prospective ECF funders during the campaign. The campaigns display all interactions between entrepreneurs and potential investors via a "Q\&A" feature. These interactions were time-stamped, highlighting the chronological dialog between entrepreneurs and potential investors. Given that SEC Regulation $\mathrm{CF}$ prohibits private offline interactions between entrepreneurs and potential funders (SEC, 2016b), this dialog represented all interactions between entrepreneurs in our selected cases and their funders. In total, data on the Q\&A portals was 318 pages cumulatively.

SEC data In order to be eligible to raise ECF in the USA, firms must file for approval using SEC Form C (SEC, 2017). We reviewed the Form $C$ filings for each company. Company disclosures in this filing revealed a great deal about the entrepreneurs and companies, including business objectives, proposed use of funds, number of employees, terms of the equity offering, legal disclosures, and financial position including assets, liabilities, revenues, profits, etc. We coded quantitative and qualitative details from each filing.

News articles and other secondary data A variety of media artifacts pertaining to each of the entrepreneurial ventures in our cases were also reviewed. These include trade-related periodicals, business press, general news outlets, and human-interest stories highlighting the entrepreneurs in our cases or the users of their products or services. In total, we reviewed 155 media artifacts (555 pages) to corroborate our findings from our other primary and archival sources, at which point we reached theoretical saturation.

ECF portals Although they did not pertain directly to our individual cases, we reviewed filings, portal websites, and press releases from five of the largest ECF portals. We sought to understand who ECF portal founders were, what their motivations were, and who supported the portals via legislation and funding. Given that press releases quoted notable supporters of ECF (e.g., President Obama, VC Marc Andreessen), these documents offered additional insights regarding how and why capable entrepreneurs might consider ECF a viable option. These five largest portals accounted for over $98 \%$ of total ECF volume in the USA.

Personal interviews with entrepreneurs and funders We conducted 16 participant interviews via phone and electronic correspondence. Given the recent emergence of ECF, the entrepreneurs we spoke with were open to sharing detailed accounts of their experience, and as a result, our access to these founders 


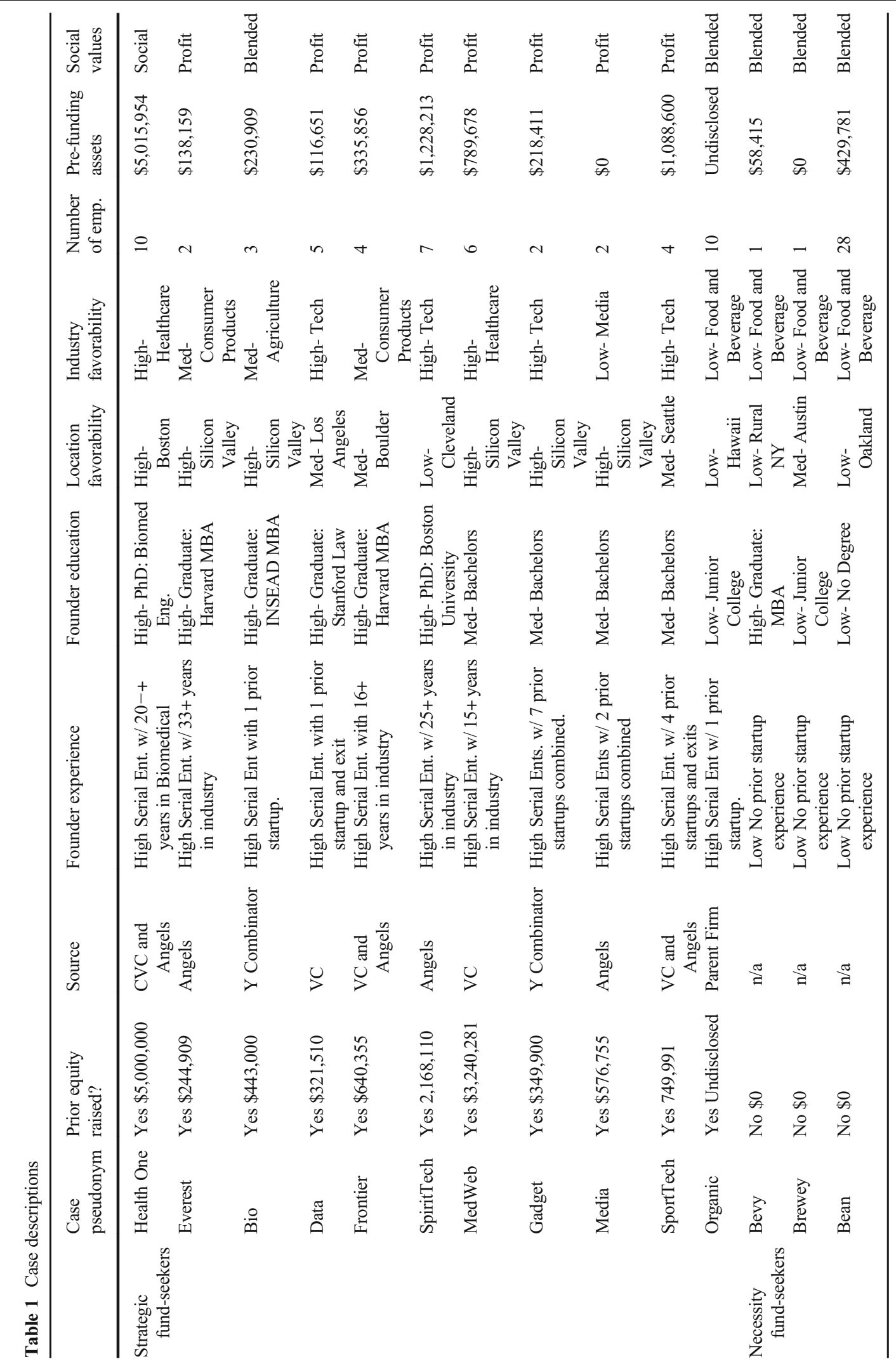


Table 2 Data sources for primary analysis

\begin{tabular}{|c|c|c|}
\hline Source & Description & Detail \\
\hline ECF campaign and pitch videos & $\begin{array}{l}\text { Each venture had a campaign page; most campaigns } \\
\text { provided additional pitch documents } \\
\text { (videos, business plans, etc) }\end{array}$ & 472 total pages \\
\hline ECF portal filings, websites, and press releases & Publically available sources; 12 artifacts & Supplemental data source \\
\hline Entrepreneur-investor Q\&A portal & Each campaign had a Q\&A portal & 318 total pages \\
\hline News articles and other secondary data & Press and Secondary sources; 155 artifacts & 555 total pages \\
\hline $\begin{array}{l}\text { Personal communications (interviews and email } \\
\text { correspondence) }\end{array}$ & Direct contact used to supplement other sources & 16 participant communications \\
\hline SEC data (required SEC filings) & Each firm filed with SEC prior to raising ECF capital & 84 total pages \\
\hline
\end{tabular}

allowed us to build information-rich case accounts. We also interviewed other market influencers, including a member of President Obama's Council on Jobs and Competitiveness to extend our understanding of ECF from the legislative perspective. Correspondences were generally used to supplement and build upon the extensive ECF artifacts that we analyzed and described above.

\subsection{Analysis}

We integrated the multiple-case analysis approach with the theory building approach developed by Gioia et al. (2013). We used this approach to identity and describe key motivations and behaviors underlying entrepreneurs' decisions to pursue ECF. We examined the data from both within-case and between-case perspectives. Within-case analysis centered on developing a thorough account of that firm's fund-raising experience. After we developed this understanding, we then began a crosscase analysis to look for the emergence of similar themes across multiple cases (Eisenhardt, 1989; Eisenhardt and Graebner, 2007). For this process, we broadly adopted the systematic approach outlined by Gioia et al. (2013) which largely follows the inductive process of Straus and Corbin (1990).

In general, we progressed through three sequential phases of analysis. First, we examined the data highlighting all instances of identifiable actions and behaviors that played a role in their pursuit or nonpursuit of ECF. At this stage, the goal was to generate as many potential themes as possible (Gioia et al., 2013) and was similar to the open-coding process of Strauss and Corbin (1998). We initiated coding by first analyzing the pitch videos and pitch decks. In these videos, it was common for fund-seekers to emphasize their vision for the company. For instance, one entrepreneur in our sample while describing his vision related to what his company could become and the types of investors he saw as a good fit for his goals emphasized:

... and that's the kind of impact I want to have on this world. To those people who believe in the vision that we can build a better technology for our loved ones with type 1 diabetes, who want to help us bridge a biological cure, these are the investors we're looking for [HealthOne].

Second, we assigned the first order code "entrepreneur vision" to this specific reference. Several other firstorder codes emerged directly from the pitch videos. As we progressed to other artifacts such as ECF campaign pages, question and answer transcripts, and SEC documents, we cross-referenced and adjusted our initial codes as our understanding of the venture evolved. We also interviewed entrepreneurs and funders, revealing additional nuances. We continued open coding until no incremental inferences or shared patterns emerged (Huy et al., 2014). While initial categories were still somewhat fluid, they served as a foundational structure upon which to aggregate second-order themes. In this process, we looked for similarities and differences among firstorder categories. This process also functions to condense the large number of initial codes to a more manageable number (Gioia et al., 2013). In total, we derived nine second-order themes.

Third, with a workable set of first-order codes and second-order themes in hand, we began developing our provisional theoretical model. We tested our interpretations by re-reviewing the data in both a confirmatory and dis-confirmatory manner (cf. Sonenshein et al., 2017). As our theoretical model evolved, we spoke with 
key informants to corroborate and/or challenge our developing schema and model (Lincoln and Guba, 1985). Our analysis ultimately concluded once we were able to parsimoniously describe the most salient elements that fund-seeking entrepreneurs considered as they pursued funding. During our analysis, we also identified a theoretically meaningful way to bifurcate and contrast our selected cases (i.e., necessity fund-seekers and strategic fund-seekers), which we describe in detail in the next section. A summary of the results of our coding appears as Fig. 1.

\section{Findings and propositions}

Our findings first revealed there were two distinct types of fund-seekers in our cases. Thus, it was appropriate to split the cases into two theoretically meaningful groups of entrepreneurs so as to not conflate their distinctive motivations for pursuing ECF. Following prior qualitative research (e.g., Hallen and Eisenhardt, 2012; Williams and Shepherd, 2016), we inductively bifurcated our cases in a theoretically meaningful way by classifying the ventures as either "necessity" fundseekers or "strategic" fund-seekers. For necessity fundseekers (3 of 14 companies), ECF was the only clearly viable path to funding. That is, our data indicated that alternative equity financing options were unavailable to them at their current stage. In general, these companies resembled lifestyle businesses (McMullen and Warnick, 2016). In contrast, 11 companies had multiple equity funding options available to them, including angel investment and VC. Thus, these entrepreneurs made a strategic choice to pursue ECF instead of their alternative equity options. We classified these companies as "strategic" fund-seekers. In general, they resembled rapid-growth ventures common in angel and VC settings (Shane, 2009; Stevenson et al., 2019b).

4.1 Two types of fund-seekers: necessity fund-seekers and strategic fund-seekers

Necessity fund-seekers Necessity fund-seekers demonstrated a number of common characteristics. First, in general, they all believed they could eventually raise other forms of capital (e.g., angel, VC) but at the current

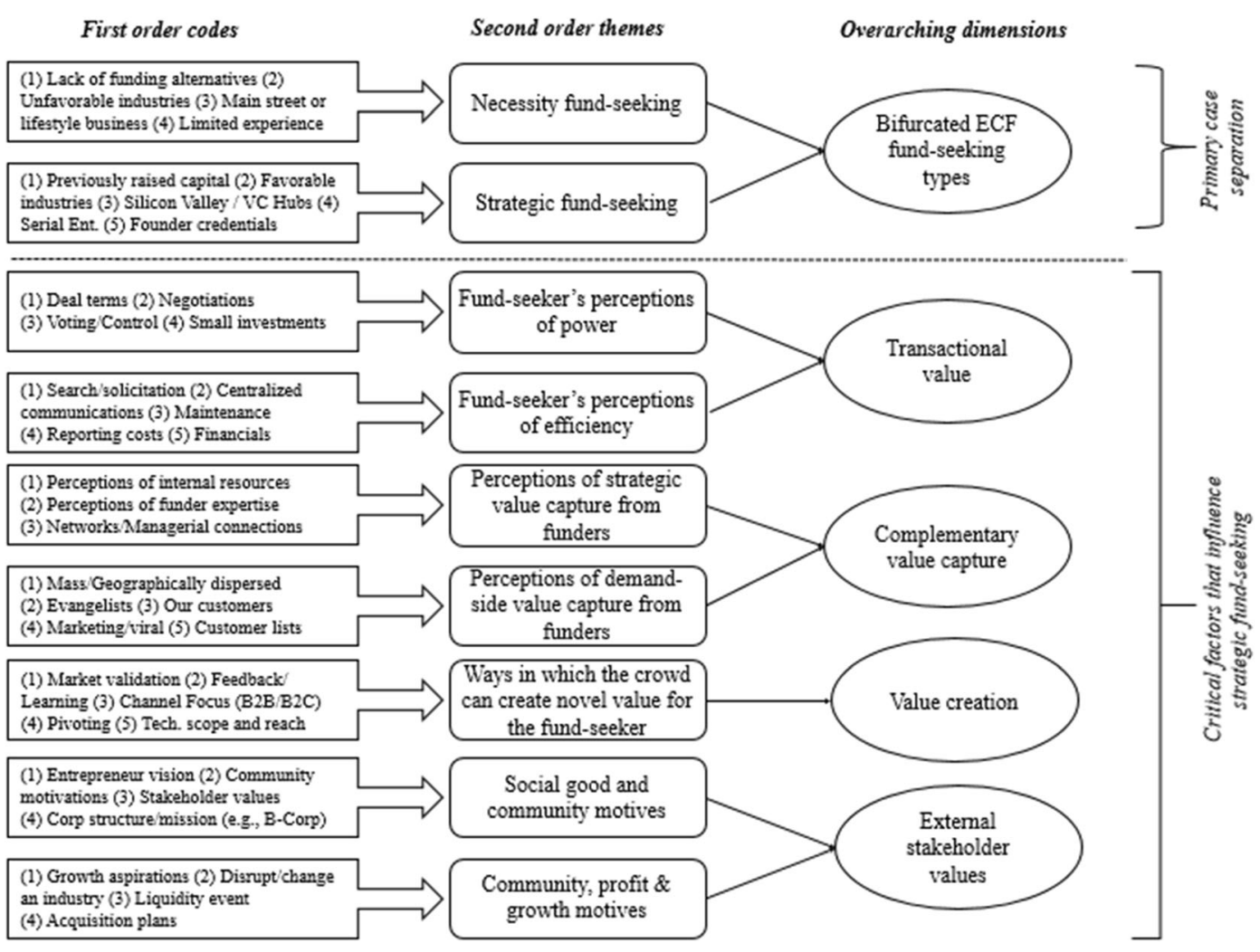

Fig. 1 Data structure 
time they felt their firms were "too early" to efficiently attract these forms of capital. Thus, necessity fundseekers were left with a Hobson's choice (cf. Nicholson, 2003) - a choice to pursue ECF or pursue no equity fundraising at all. Second, necessity fundseekers were based in regions typically underserviced by professional equity sources - referred to in the literature as "main street" locations or places of "everyday entrepreneurship" (Welter et al., 2017). Scholars note that these are locations where the majority of entrepreneurship actually takes place, but these regions attract almost negligible interest from traditional equity investors (Stevenson et al., 2019b). Third, necessity fundseekers were operating in two industries: Consumer Products and Food \& Beverage. These industries have been largely ignored by traditional investors, collectively accounting for less than $3 \%$ of the VC market during the prior 5-year period (PWC, 2017). One of the entrepreneurs explains his industry-related challenge:

\section{I went in. Sat down in the conference room across} from a 65-year old woman in a business suit. Pitched my idea. She looked down at the table, picked her head up, looked back at me and said 'we really have no interest in the brewing industry, and don't really feel like it's a viable option'

[Brewery].

Fourth, with regard to human capital, necessity fund-seeking founders had limited previous startup experience. Two of the necessity fund-seekers were first time entrepreneurs, while one had been involved with a few small startups in the past. From an education standpoint, one founder had a graduate degree and the other two had no college degree. Fifth and finally, necessity fund-seekers tended to have low social capital in terms of their connection to angels and VCs. Lack of social capital may have discouraged these necessity fund-seekers from pursuing other sources of equity because they believed the odds of raising other external equity funding was very low. Collectively, in line with prior work that has found ECF to attract discouraged entrepreneurs, these data support that necessity fundseekers were extremely limited in their funding options and that they pursued ECF due to such constraints. However, the same was not observed when considering the strategic fund-seeker cases described in the next section.
Strategic fund-seekers Eleven companies were classified as strategic fund-seekers. In determining this classification, we looked at several indicators from our dataset. First, strategic fund-seeking entrepreneurs were highly experienced. SpiritTech's founder had extensive corporate and new venture experience over a 25-year career. HealthOne's founder had been working on his current venture for more than 8 years using the $\$ 5$ million previously raised to advance his technology through multiple stages of FDA trials, including human trials via a partnership with a Fortune 200 firm. The founder of Data was a serial entrepreneur with multiple exits. Frontier's founder had 16 years of startup experience and many years of experience working in finance, including a stint with the SEC in the private equity division. Collectively, the two founders of Gadget had been involved in seven startups, while the founders of Everest and MedWeb were in their second startup and had 33 and 15 years of industry experience, respectively. In terms of education, two of the founders had PhDs, one in biomedical engineering and one in marketing. Four others had graduate degrees, including two Harvard MBAs, One INSEAD MBA, and one Stanford Law degree. The other founders had bachelor's degrees from well-respected institutions.

With regard to social capital, many of the strategic fund-seekers had close connections with highly respected entrepreneurship institutions. For instance, a number of founders were graduates from well-known accelerators and incubators, including Y Combinator. Others had the public support of angels and VCs. For example, Data had a public endorsement from Marc Andreessen, one of Silicon Valley's most prominent VCs. Specifically, Marc Andreessen noted "[Founder] is the most brilliant community creator we've seen since Caterina Fake's heyday at Flickr". Another company, SportTech was endorsed by Phil Nadel, Director of a NYC-based VC firm, who said:

What attracted us to [SportTech] was a combination of 3 things. First, the experienced team that has worked together for years prior and has the know-how to take the business from a startup phase to a fast-growing, profitable organization. Second, traction with over $\$ 6 M$ in sales to date, they're proving market validation. And third, the product itself [SportTech]. 
In terms of previous fund-raising capacity, all of the firms that we ultimately classified as strategic fundseekers had previously raised an angel or VC round with their current or prior startups. For instance, HealthOne had previously raised more than $\$ 5$ million in $\mathrm{VC}$ funding in exchange for $5 \%$ of their company, giving them a pre-money valuation of $\$ 100$ million at the time of their ECF round. When asked by a potential ECF funder, "Why are you raising [ECF]? It looks like you can go to any VC?", HealthOne's CEO replied, "Our decision to turn to [ECF] was driven less by a need for capital than by our desire to enable individuals impacted by [Type 1 Diabetes] to directly contribute [our] success." Other strategic fund-seekers also had previously raised capital from prominent VC firms, including Greylock Partners, Khosla Ventures, and Andreessen Horowitz, as well as prominent angels including Barbara Corcoran from ABC's Shark Tank. On average, the strategic fund-seekers raised $\$ 1.1 \mathrm{M}$ from other sources prior to their ECF rounds. The mean premoney valuation of the strategic fund-seekers was USD\$ 16.8 million. With substantial pre-money valuations and established VC relationships, our data confirmed the decision to seek ECF was a strategic choice for the firms that were classified as strategic fundseekers.

In contrast with necessity fund-seekers, strategic fund-seekers were also operating in sectors that tend to attract a lot of attention from angels and VCs, such as Internet, Tech, Healthcare, and Agriculture. Collectively these highly favored industries accounted for $85.7 \%$ of all VC deals over the prior 10-year period (PWC, 2017). These firms were predominantly in regions that angels and VCs typically favor. Five were located in Silicon Valley and others were located in Boston, Seattle, L.A., and Boulder. These regions are hubs of professional investment activity (Florida and Mellander, 2016). There was one notable exception. Organic was based in Hawaii, a region largely ignored by angels and VCs, accounting for only $0.04 \%$ of all $\mathrm{VC}$ deals over the prior 10 -year period (PWC, 2017). However, Organic's parent company was growing at a rapid pace and had previously closed an angel round.

We were interested in the underlying factors that influenced fund-seekers who had equity choices. Thus, after bifurcating our cases, we focused the majority of our subsequent analysis on the strategic fund-seekers cases. Specifically, we sought to identify the critical factors that lead these strategic fund-seekers to choose
ECF over alternative equity options that they could have otherwise pursued. Our motivation was similar to prior research that has focused on understanding the critical factors underlying investor behaviors (e.g., Maxwell et al., 2011); however, we diverge from prior work by shifting the focus of our analysis to entrepreneurs rather than investors. Despite their human and social capital, and notwithstanding their demonstrated ability to raise capital from traditional equity funders, these highly capable strategic fund-seekers chose to seek ECF. In the next section, we identify and unpack four distinct factors from the point of view of strategic fund-seekers that influence perceptions of funding fit: (1) transactional value, (2) value capture from funders, (3) value creation from the fundraising process itself, and (4) external stakeholder values. Figure 2 illustrates the overall conceptual model derived from this research.

\subsection{Transactional value}

Power Prior research demonstrates that to retain power, angels and VCs often impose contractual covenants such as voting shares, board seats, first right of refusal, delayed equity vesting schedules, and the power to remove founders (Bartlett, 1999; Hellmann and Thiele, 2015; Rosenstein, 1988). Entrepreneur's demands for strategic control, of course, can only occur if their investors capitulate during the negotiating process. While this rarely occurs in angel or VC deals (Wasserman, 2008), we found that it was commonplace in ECF deals. Indeed, our data revealed that all of the strategic fundseekers in our cases offered ECF funders non-voting or limited-voting shares only, leaving full strategic power in the hands of the entrepreneur. Health One's share setup described below was typical:

\section{Our offering is set up as a direct investment in (The Company), with each investor receiving shares of the company's non-voting Class C Com- mon Stock [HealthOne].}

We also did not find "first right of refusal" clauses for future funding rounds and share vesting, which are common covenants in angel and VC deals, in our cases. In addition, novel terms favoring the entrepreneur were common. For example, term sheets included a buy back clause for the entrepreneur, meaning the entrepreneur could buy out any funder. This would be an extremely rare clause on seed-stage $\mathrm{VC}$ or angel investor term 


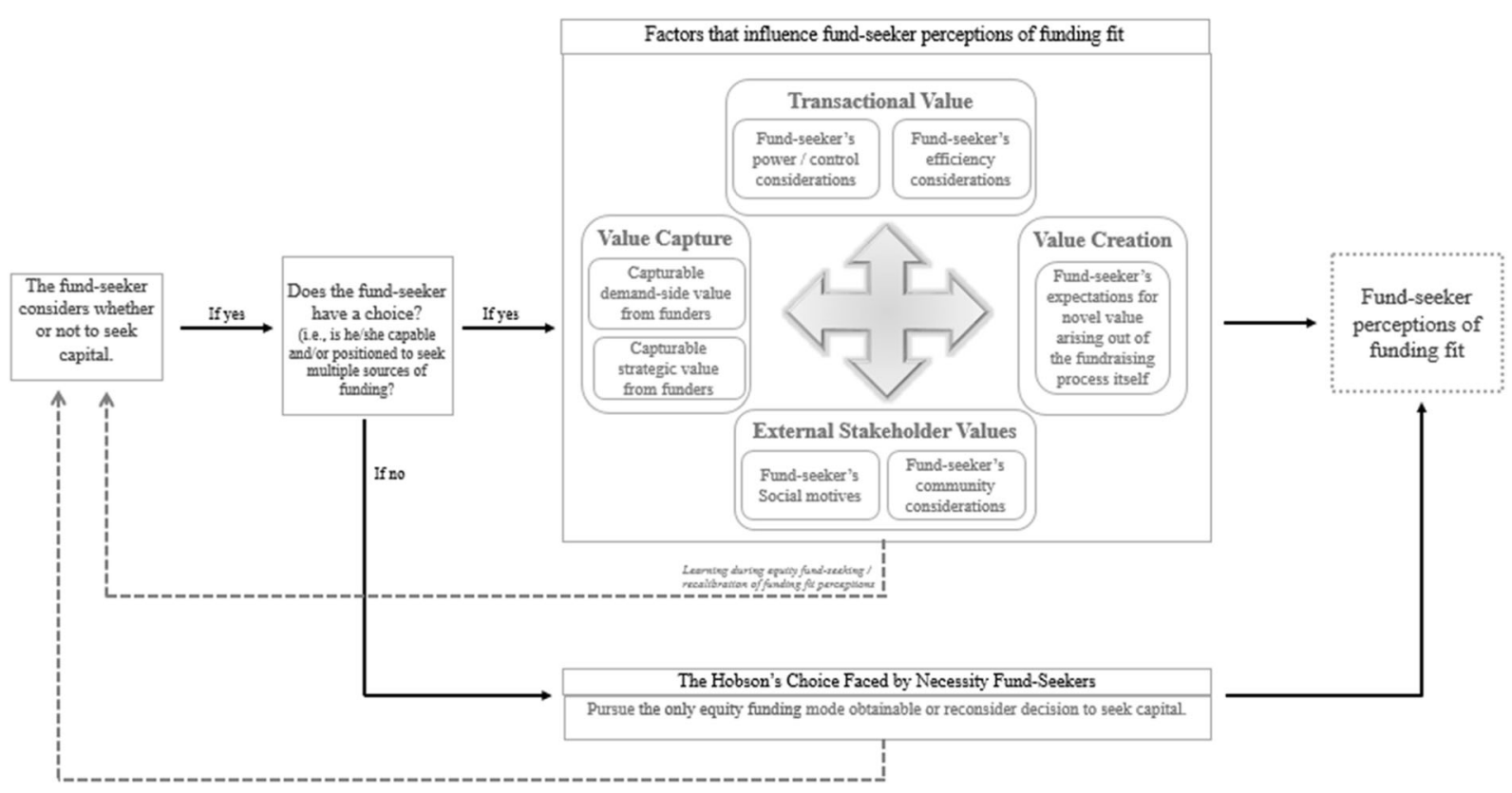

Fig. 2 Conceptual model

sheets. As well, in certain cases, the ventures created a specific class of stock for the ECF offering. By design, this class of stock limited the rights and powers of ECF funders, removing privileges commonly associated with new venture funding deals based on prior research. Bio and Media explained their rationale:

It would have been administratively prohibitive to provide such rights to the large group of investors participating in the crowdfunding offering. Additionally, for business reasons, preferred stock is usually reserved for strategic partners and financial institutions that typically make significantly larger investments [Bio].

There are two classes of stock. Class A shares is what we've sold in all of our equity crowdfunding rounds to date. [Founder] shares (as well as some employees, founding creative allies, seed investors, etc.) are Class B shares, which have a $10 X$ voting preference. This allows [the founders] to retain voting control of the company even if we own less than $50 \%$ of the stock. This dual class structure is modeled after the structures in place at companies like Berkshire Hathaway, Google, Facebook, etc. It's designed to concentrate the voting power in the hands of the founders, which we think is the right model. [Media].
Prior research also shows that in order to mitigate longterm contractual hazards, angels and seed-stage VCs commonly require complex deal terms to ensure that they have a mechanism in place to fire the company managers in the event of non-performance (cf. Khanin et al., 2009). Bartlett (1999) showed that it was quite common for VC firms to force out the founding entrepreneurs and key managers from the firms they funded. In contrast, none of the ECF deals we studied provided any power for ECF funders to exercise similar ex post control:

Unlike the holders of common stock in a corporation, (ECF investors) will have no voting rights on matters affecting our business, and therefore investors will not have the ability to influence decisions regarding our business. Furthermore, if our (ECF investors) are dissatisfied with the performance of (The Management Team), they will have no ability to remove or replace our (Management Team) [SportTech].

As another way to maintain control and reduce agency costs, angels and seed-stage VCs also commonly mandated that funded ventures disclose relevant financial information on an ongoing basis. In contrast, the entrepreneurs explicitly noted that ECF funders would not be provided with frequent detailed updates. As Drover 
et al. (2017) argue, ECF has the potential to shift new power to the entrepreneur, representing a disruption to standard practices with notable implications for theory. Our data is in line with this suggestion. Strategic fundseekers were highly motivated to raise capital using ECF platforms in order to avoid losing power and strategic control that they felt would otherwise be standard in traditional deals:

\section{Everybody knows that VC's try to retain all the} power. That is exactly what turned us off from the $V C$ route [Everest].

Overall, the strategic fund-seekers acknowledged that retaining strategic power was one of their primary motivations for pursuing ECF. These entrepreneurs were aware that, in contrast to ECF, attracting investment from $\mathrm{VC}$ or angel sources would require them to give up autonomy and relatively more control over most expost decision making (cf. Wasserman, 2008). Strategic fund-seekers in our sample were highly motivated to pursue ECF because of the contractual power that they believed they could retain ex post. Formally, we propose:

Proposition 1a. Power retention concerns increase entrepreneurs' perceived funding fit for ECF.

Efficiency Strategic fund-seekers also identified another advantage of ECF in that it was efficient and not overly time consuming. Prior research demonstrates that traditional fundraising requires considerable time, effort, and money (Gompers and Lerner, 2004), often incurring high costs related to identifying, evaluating, traveling to, and interacting live with potential funders. In contrast, ECF was enacted in order increase the pool of potential investors available to fund startups, with the overarching goal of increasing capital raising access and efficiency for new firms. This perspective is clear in many regulatory documents and announcements including the following statements from the White House press secretary when ECF was officially announced:

\footnotetext{
"[This] Act will allow Main Street small businesses and high-growth enterprises to raise capital from investors more efficiently" [The White House Office of the Press Secretary].
}

The entrepreneurs and investors in our sample also discussed several search and solicitation efficiencies that their firms derived from ECF. In general, one of the major advantages of ECF its perceived efficiency in terms of search and solicitation relative to other funding forms:

\section{"(ECF) will shorten the time and expand the scope of fundraising cycles, especially for B2C companies that can easily convey their value proposition if they create compelling digital me- dia to support their company's narrative, and distribute that media effectively through relevant platforms." [Angel Investor \&Industry Expert]}

In terms of dealing with funder inquiries, entrepreneurs described the process of responding to potential funder inquiries as time-consuming, but not more so than pitching to traditional equity investors. One inconvenient difference was that ECF funder questions could appear online at any time, and most entrepreneurs felt like they were "on call" and needed to respond quickly to inquiries during their campaign. Some entrepreneurs would respond within hours, while others would take days or weeks to reply. To increase efficiency, entrepreneurs tended to craft "canned responses" for common questions. For instance, if an entrepreneur was asked about valuation or exit strategy by a potential funder, the entrepreneur would develop a detailed answer and post it on the Q\&A portion of their campaign page. If that question was proposed again weeks later by another funder, the entrepreneur would reference the earlier response or repost it. Entrepreneurs in our sample indicated that they perceived the ECF to have significant efficiency benefits relative to other funding options that they otherwise had access to. Several strategic fundseekers noted that one of the primary reasons they pursued ECF is because they believed it would maximize transactional fundraising efficiency. Formally:

Proposition 1b. Transaction efficiency concerns increase entrepreneurs' perceived funding fit for ECF.

\subsection{Value capture from funders}

Prior research has identified that entrepreneurs often benefit by capturing complementary strategic value from traditional funders in the form of coaching (Ciuchta et al., 2018), management expertise (Baum 
and Silverman, 2004), and other forms of strategic funder expertise (Fitza et al., 2009). Traditional venture investors "increase the professionalization of their portfolio companies by bringing in professional managers, standardizing HR policies, hiring marketing executives, adopting stock option plans (Hellmann and Puri, 2002), and facilitating the adoption of other professional management systems" (Fitza et al., 2009, p. 390). In these traditional venture funding deals, the transfer of strategic value from investors to entrepreneurs is facilitated through close person-to-person interactions that occur prior to (e.g., pitch meetings) and after the transaction (e.g., board meetings).

We probed our data to assess the perceptions that fund-seekers had about the likelihood that they would or could capture strategic value from ECF funders. In contrast with prior venture funding research, which stipulates that venture investors often bring extrafinancial strategic expertise to the firms they fund (Ciuchta et al., 2018; Fitza et al., 2009; Hellmann and Puri, 2002; Park and Steensma, 2012), the entrepreneurs in our cases did not expect to source strategic guidance from ECF funders. Indeed, the entrepreneurs seemed to be well aware that pursuing ECF meant they would have to actively trade-off access to strategic funder guidance that they could otherwise capture with angel or VC deals. Some entrepreneurs even believed that efforts to tap the crowd for strategic guidance would hinder progress:

It's not that useful having 100 people give you strategic advice without knowing the full picture. It becomes more of a distraction I think. If you want managerial connections, you are going to be better off going to angel investors, because that's what they provide... 'cause they have more skin in the game. [Bio]

Overall, our findings pointed to an interesting divergence from the extant equity funding literature, which tend to demonstrate that one of the primary benefits of early-stage equity transactions accumulates from the strategic expertise that entrepreneurs capture ex-post (Baum and Silverman, 2004; Ciuchta et al., 2018; Park and Steensma, 2012). Data from regulatory body disclosures also further confirmed that, unlike traditional equity relationships, it was prudent for entrepreneurs to expect that very little (if any) strategic value could be capturable in ECF deals. In a bulletin to prospective funders, the SEC (2016c) provided cautionary guidance:

Many successful companies partially attribute their early success to the guidance of professional earlystage investors (e.g., angel investors and venture capital firms). An earlystage company financed through crowdfunding may not have the benefit of such professional investors [SEC].

Our data revealed another interesting divergence from the prior complementary value literature. Although entrepreneurs did not perceive that they could capture nonfinancial strategic value in the form of management expertise from ECF funders, they did believe that they could capture a different type of complementary value from ECF funders:

Strategically, having a large, engaged group of shareholders has the potential to be a very valuable distribution channel for launching new products. If you have 1000 investors, and they all have 1000 Facebook friends, and their willing to tweet your product launch, that's a million people that could see your launch. And that's a pretty valuable strategic resource [Bio].

While it's true that one individual may not replace the value add of an entire $V C$, we believe there may be a significant upside of having hundreds of small-time investors behind our product and company [Gadget].

The more people hear about and learn about our (products), the larger our audience grows. The addition of crowdfunding equity will only help grow our army of evangelists [Everest].

These quotes demonstrate that strategic fund-seeking entrepreneurs perceived they could garner demandside complementary value from ECF funders. Demand-side complementary value includes mass referrals, prospective customer lists, free social promotions, and the generation of hype that only a large group of supporters could provide. This type of complementary value appears to be unique to ECF (relative to angel/VC) and has not been the focus of prior research. Entrepreneurs also regarded ECF as a way to strengthen customer relationships. SpiritTech's rationale was typical, "selling stock to customers is a good way to build a closer bond with them." Gadget 
recognized the demand-side value capturable from a large shareholder base:

In a single day we had 1 million views. People everywhere were chiming in about how psyched they were for the (product) and now we already have 40,000 customers in the pipeline [Gadget].

Throughout the campaign, Gadget was highly engaged with their funders, promptly responding to every inquiry. They leveraged initial relationships to secure presales, a list of early adopters, and a viral video that generated 5 million views. They also did something unprecedented in early-stage funding deals. They generated revenue from their base of funders and other potential customers by selling \$10 VIP cards. When Gadget's initial inventory run was completed, customers with these cards would receive the product first. Gadget appeared to be highly strategic when it came to considering the extent to which they could leverage existing funders to capture demand-side complementary value. Although no other company used the same revenuegenerating strategy that Gadget used, many of the other entrepreneurs did deliver multi-pronged messages, as demonstrated by Frontier, "We look forward to the opportunity to serve you as both an investor and a customer!" Thus, although it was used to differing degrees by strategic fund-seekers, all of the strategic fundseekers in our sample identified the value of capturing demand-side complementary value from ECF funders.

Proposition 2. Concerns for demand-side complementary value increase entrepreneurs' perceived funding fit for ECF, whereas concerns for capturable strategic value from funders do not increase entrepreneurs' perceived funding fit for ECF.

\subsection{Value creation from the fundraising process itself}

Unlike capturable strategic value described above, we observed that fund-seekers pursuing ECF were also enamored with a novel type of value born directly out of the ECF fundraising process itself. We refer to this as market validation information, defined as aggregate indications from a cross-section of individuals that a venture's prototypes, products, or services meet minimally viable specifications. Market validation information is similar to capturable complementary value in that it also is valuable and coveted by entrepreneurs.
However, unlike capturable complementary value, market validation is not a tangible resource possessed by individual funders a priori. Rather, market validation information is created through a collaborative vetting process which pulls together a broad assortment of diverse crowdfunders. Entrepreneurs in our study considered market validation information a valuable complementary resource that came part and parcel with ECF processes. When asked about what value the crowd could provide related to validation, Gadget noted, "There are so many uses and every day [ECF funders] come up with new ones." Other fund-seekers also noted:

\begin{abstract}
Throughout the raise we tried to stay connected, tried to engage them, ask them what they knew about the company. People from around the country, and around the world. They had different viewpoints. It's almost like a better way to research your market [Everest].

We believe a Legion of (user)-investors is a massive asset when it comes to helping us find and evaluate [new product opportunities]... We invest an enormous amount of effort building systems and initiatives that leverage the wisdom of the crowd [Media].

Obviously this is all very new and we'll see how this works out and less experienced investors will have a different skillset to our existing investors, but I expect having many smaller investors will be useful, for instance, for testing market reaction to new product ideas [Bio].
\end{abstract}

In this way, our data revealed the process of pursuing ECF created value for entrepreneurs as "crowd" reactions and feedback to the ECF campaign represented a novel source of validation information. Notably, this value was collectively created from the process itself, rather than captured from existing resource stockpiles. Thus, strategic fund-seekers suggested the crowd was able to teach them something that even highly experienced VCs could not. In terms of its specific value, the market validation information derived from ECF processes provided entrepreneurs granular details on specific regions and types of consumers that they believed were most interested in their products. As well, it provided entrepreneurs with insights on what products were valued most by a large user base, informing potential product pivots: 
The process resulted in insights into which version (of the product) resonated best with different demographics [Media].

Based on the sheer size and geographic dispersion of the crowd, entrepreneurs gained valuable qualitative and quantitative validation data about the potential for wide-scale acceptance and scalability. Although validation data derived from ECF markets is not a perfect signal of overall market validation derived only from the market, the entrepreneurs in our cases did expect that it provided a signal of market acceptance. Formally, we propose:

Proposition 3. Market validation considerations increase entrepreneurs' perceived funding fit for ECF.

4.5 External stakeholder values (e.g., social motives and community values)

Prior literature has shown that rewards-based crowdfunding campaigns facilitate investments based on non-financial values including social good (Lehner, 2013). As part of our analysis, we investigated if the desire to build social and community value was also salient for the strategic fund-seekers in our cases. While several entrepreneurs expressed some enthusiasm for creating social good, only one company, HealthOne, had taken the necessary steps to register as a certified benefit corporations (B Corp). B Corps certification allows companies to affirm their organizational commitment to positive environmental and social practices (Gehman and Grimes, 2017):

We incorporated as a [B Corp] specifically because we wanted to be able to prioritize our public benefit mission over providing investors with a return on invested capital. Our overriding commitment is to act in the best possible interest of the [Type 1 Diabetes] community. This is our guiding principle, and our benefit corporation structure empowers us to do this. As such, we seek likeminded investors whose interests are in seeing HealthOne succeed in serving its benefit mission over any ROI their money might otherwise bring. As a public benefit corporation, we are under no obligation to provide a return on investment to shareholders.
Although B Corp certification is one way to classify social enterprising, scholars also note that founders with blended value mandates can also be classified as social entrepreneurs (Wry and York, 2015). Two of the 11 strategic fundseekers fell into a blended value classification. These firms emphasized their goal to blend profit with social value, noted below:

To preserve tomorrow, we should take from the earth only what we can [Bio].

Incorporating the community into our business... we want them to a shareholder and a stakeholder of everything we do [Organic].

These blended-value firms stopped short of making their social motives their primary objectives. In speaking with "blended" founders, it was clear they believed strongly in their social missions, but also understood that the foundation of ECF is built on capitalistic incentives and that developing shareholder value needed to be a key consideration for their firms. Thus, they integrated both social and profit institutional logics and developed a dualistic sense-giving approach (Sharma and Good, 2013). Founders believed that it was this dualistic approach that made their investment opportunity unique and valuable relative to other opportunities. In contrast, they expected angels and VCs to think with their head, not with their heart. The vast majority of firms in our cases were classified as "profit-centric" (i.e., firms that signaled their primary focus was on generating economic value over social or community value).

Proposition 4. External stakeholder value considerations increase perceptions of funding fit for ECF, but these concerns are prioritized lower than transaction value, value capture, and value creation considerations.

4.6 Putting it all together: entrepreneur perceptions of funding fit

We define funding fit as fund-seeker perceptions about the suitability of funding types for his or her own unique venture at its current stage of development. Four elements of funding fit emerged in the context of ECF: (1) transactional value, (2) value capture from funders, (3) 
value creation from the fundraising process itself, and (4) external stakeholder values.

Consistent with prior theorizing which states that entrepreneur-investor relationships are temporally contingent (see Cummings et al., 2020), our data revealed that an entrepreneur's assessment of funding fit unfolds over time. This temporal process is captured in our conceptual model via the learning feedback loop (see Fig. 2). For an example, consider Everest's founder's journey of discovering funding fit. Even though Everest's founder had previously raised VC capital, when the opportunity for ECF arose, he started to contemplate ECF as a potential fit for his business. One board member persisted, proclaiming that the ECF model was different and that it might be the appropriate fit for Everest. Eventually, that board member bought a ticket to a local ECF conference in the Bay area and persuaded Everest's Chief Operating Officer to attend the event. After that, as Everest's Chief Operating Officer explains:

\section{It just started to feel like a perfect match. Each person that invests in your company is also now like a new evangelist. And that really hit home for us.... Traditional funders aren't as into the idea of building a brand, or something that involves phys- ical products and manufacturing. They are enam- ored with the tech world and with how fast things can happen there. And you can't blame them for it, because there are so many success stories in the press and what not. Everyone has big eyes for that stuff, and we just realized we are not looking for that type of funder... We actually want to find partners, you know people that actually believe in what we are trying to do, and want to grow it that way, rather than just trying to strike the lottery.}

Likewise, even though Frontier's founder had previously raised $\mathrm{VC}$ funds in a prior business (prior to the legalization of ECF), once ECF became an option his perceptions on the most appropriate funding fit for his business changed. He had high expectations for ECF and when asked about the potential fit of VC for his current business at the current time, he replied:

I went to Harvard Business School, so I don't ever want to work with a VC. I know what they do! (laughs). Everything in that whole realm is geared toward building something really fast, really big, scaling it, and selling it, it's all really just about money. And [ECF] is certainly about money, but there is something more real at the heart of it, and in my experience, the things that make the most money long-term are the things that are real. I want to build something really big, really strong, really great with investors who understand it... who value the products themselves, and want to see it grow properly over decades, not half a decade. None of that points VC. None of that points to anything traditional. All of that points to getting your customers on board.

Overall, our data demonstrated that entrepreneurs tended to be highly intentional in their fundseeking behaviors. The strategic fund-seekers in our cases were cognizant that there were alternative funding modes available to them. Yet, they still perceived ECF to be a superior fit for their businesses at the given point in time (they did not imply that ECF would always be the best fit). Thus, at least for strategic fund-seekers in our sample, ECF was not pursued as a backup funding source, but rather as a preferred funding source given their perceptions related to several critical factors. Each of these factors are presented in our model (see Fig. 2). Last, in all of our cases, entrepreneurs identified the dynamic and reflexive nature of funding fit from their perspective. No strategic fund-seeker in our sample mentioned a rule-based "pecking order" as a guiding principle for their decision to pursue ECF. Table 3 provides illustrative quotes.

\subsection{Robustness checks and post hoc assessments}

Our data collection focused on an "initial cohort" of firms. From this cohort, we derived a model of funding fit preferences from our analysis, but we acknowledge that this conceptualization of fundseeker considerations is likely incomplete given the specificity of our sampling frame. In other words, because this cohort was part of the emergence of ECF, one might wonder the extent to which the companies would be comparable to companies that subsequently raised ECF. To account for this concern, we conducted supplemental analyses of SEC filings to compare our cohort 
Table 3 Representative quotes for each dimension of funding fit for ECF fund-seekers

\begin{tabular}{lll}
\hline $\begin{array}{l}\text { Overarching Second order element } \\
\text { theme }\end{array}$ & Representative quotes
\end{tabular}

theme

\begin{tabular}{cc}
\hline $\begin{array}{c}\text { Transactional } \\
\text { value }\end{array}$ & $\begin{array}{c}\text { Retaining power via ECF relative to other } \\
\text { equity funding modes }\end{array}$
\end{tabular}

Transactional value

Strategic value capture

Strategic value capture
Efficiency of ECF relative to other equity funding modes
"Unlike the holders of common stock in a corporation, (ECF investors) will have no voting rights on matters affecting our business, and therefore investors will not have the ability to influence decisions regarding our business. Furthermore, if our (ECF investors) are dissatisfied with the performance of (The Management Team), they will have no ability to remove or replace our (Management Team)."-SportTech

"It would have been administratively prohibitive to provide such rights to the large group of investors participating in the crowdfunding offering. Additionally, for business reasons, preferred stock is usually reserved for strategic partners and financial institutions that typically make significantly larger investments."-Bio

"Voting \% is a different story. As you noted above, there are two classes of stock. Class A shares is what we have sold in all of our equity crowdfunding rounds to date. [Founder] shares (as well as some employees, founding creative allies, seed investors, etc.) are Class B shares, which have a $10 \mathrm{X}$ voting preference. This allows [the founders] to retain voting control of the company even if we own less than $50 \%$ of the stock. This dual class structure is modeled after the structures in place at companies like Berkshire Hathaway, Google, Facebook, etc. It's designed to concentrate the voting power in the hands of the founders, which we think is the right model."-Media

"Everybody knows that VC's try to retain all the power. That is exactly what turned us off from the VC route."-Everest

"There is more time committed to getting meetings set up with traditional investors as opposed to ECF where you have a fairly large audience readily available... The portal that we used was incredible to work with and I do not think I'd change anything about our experience.... Raising money this quickly makes my life easier."-Brewery

"[This] Act will allow Main Street small businesses and high-growth enterprises to raise capital from investors more efficiently"-The White House Office of the Press Secretary (when ECF was announced)

"Title III will shorten the time and expand the scope of fundraising cycles, especially for B2C companies that can easily convey their value proposition if they create compelling digital media to support their company's narrative, and distribute that media effectively through relevant platforms."- Angel Investor \&Industry Expert

"It has not been overly burdensome at all. It is important to communicate regularly but that's important with any investor. $[\mathrm{ECF}]$ made it incredibly easy for us to provide updates and manage communication through their site as opposed to trying to manage emailing."-Brewery

"It's not that useful having 100 people give you strategic advice without knowing the full picture. It becomes more of a distraction I think. If you want managerial connections, you are going to be better off going to angel investors, because that's what they provide... 'cause they have more skin in the game."-Bio

"Many successful companies partially attribute their early success to the guidance of professional earlystage investors (e.g., angel investors and venture capital firms). An earlystage company financed through crowdfunding may not have the benefit of such professional investors."-SEC

"We do not believe a very large group of fans (most of whom have little or no business experience) are interested or well suited for corporate governance of a startup company."-Media

"That's why a (user)-owned company is such a revolutionary idea. By allowing people to be a part of the process, (we are) building a community 
Table 3 (continued)

\begin{tabular}{lll}
\hline $\begin{array}{l}\text { Overarching Second order element } \\
\text { theme }\end{array}$ & Representative quotes \\
\hline
\end{tabular}

theme

Value creation Novel value arising out of the ECF fundraising process itself

\section{External stakeholder values}

\section{Entrepreneur's social motives}

and fanbase that is invested in projects even before they are released. That has the potential to create huge value for everyone"-Media

"Having a large, engaged group of shareholders has the potential to be a very valuable distribution channel for launching new products. If you have a 1000 investors, and they all have 1000 Facebook friends, and their willing to tweet your product launch, that's a million people that could see your launch. And that's a pretty valuable strategic resource."-Bio

"Selling stock to customers is a good way to build a closer bond with them"-SpiritTech

"We look forward to the opportunity to serve you as both an investor and a customer!"-Frontier

"While it's true that one individual may not replace the value add of an entire $\mathrm{VC}$, we believe there may be a significant upside of having hundreds of small-time investors behind our product and company."-Gadget

"The more people hear about and learn about our (products), the larger our audience grows. The addition of crowdfunding equity will only help grow our army of evangelists."-Everest

"We believe a Legion of (user)-investors is a massive asset when it comes to helping us find and evaluate [new product opportunities]... We invest an enormous amount of effort building systems and initiatives that leverage the wisdom of the crowd-Media

"Throughout the raise we tried to stay connected, tried to engage them, ask them what they knew about the company. People from around the country, and around the world. They had different viewpoints. It's almost like a better way to research your market."-Everest

"Less experienced investors will have a different skillset to our existing investors, but I expect having many smaller investors will be useful, for instance, for testing market reaction to new product ideas."-Bio

"There are so many uses and every day [ECF funders] come up with new ones"-Gadget

"The process resulted in insights into which version (of the product) resonated best with different demographics."-Media

"We do not expect the dollar amount of this raise to move the needle for us much, but it feels like the right thing to do from a values and philosophic standpoint."-MedWeb

"We seek like-minded investors whose interests are in seeing HealthOne succeed in serving its benefit mission over any ROI their money might otherwise bring."- - HealthOne

"To preserve tomorrow, we should take from the earth only what we can."-Bio

"[ECF] allows us to expand our shareholder base to also include other individuals that really believe in our mission and what we are trying to accomplish"-Gadget

"Incorporating the community into our business... we want them to be a shareholder and a stakeholder of everything we do."-Organic

"donating to local non-profits and supporting community growers and producers"-Brewery

"We've received several unsolicited investment offers from [our users] over the years, and our main objective with this campaign is to finally allow them an opportunity to invest in the company."-MedWeb

"The company also encourages its workers to volunteer once a month for nonprofits around the [local] community"-Organic 
with other firms raising ECF. These filings revealed that our sample was comparable to the extended population of companies raising ECF in terms of age and fundraising characteristics. Our cases had been in business for 3 years on average and were seeking $\$ 741,428$. By comparison, companies in the extended population had been in business for 2.3 years and were seeking $\$ 651,502 .^{3}$

As an added robustness check to assess whether strategic fund-seekers in our sample were representative of firms that raised equity from other sources, we considered the average post-money valuations of each strategic fund-seeker during their ECF round (median = USD \$11.95 million). These post-money valuations are well in line with the average valuations of angel or VC series A rounds. To double check this, we calculated the average $\mathrm{VC}$ deal in each industry for the reference companies in our sample. The median overall value for comparability was USD \$9.78 million. Next, we conducted a follow-up analysis and found the majority of the strategic fund-seekers had raised a follow-on Series A equity rounds at a subsequent point in time after their ECF funding round closed. The mean follow-on equity round after the ECF round studied in this research was 21.7 million. With regard to firm survival, we conducted a follow-up check on each of the strategic fund-seeking firms in our primary sample. One hundred percent $(100 \%)$ of the firms still have a functional web-presence, indicating a generally high survival rate for the strategic fund-seekers in our sample. While investigating the survival of ECF funding firms is a very interesting research question and one worthy of exploration, we did not focus on this in our primary analysis, given our specific focus on the antecedents of ECF rather than the long-term outcomes.

Finally, given that our sample consisted of a small number of early ECF adopters, data sufficiency may be a concern. To test for the robustness of our original, extensive qualitative research, we examined additional ECF firms to determine whether or not recently funded firms using ECF were qualitatively similar to, or different from, the original dataset. Specifically, we looked into the 14 most recent firms that completed ECF rounds in 2020 and 2019 (we excluded firms starting in

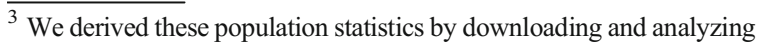
every Equity Crowdfunding Form $\mathrm{C}$ filed with the SEC at the time of writing.
}

February 2020 due to the exogenous shock of COVID-19 that might have made comparisons to the original data difficult). In reviewing data from these firms, we confirmed that - like the original samplethe firms were predominately strategic fund-seekers (reflecting factors such as prior funds raised, prior startup experience, attractive industries, attractive geographic location, and so on). Similar to our original sample, a minority of firms also appeared to be pursuing ECF as necessity fund-seekers. An indication that startups utilizing ECF were mostly necessity fundseekers might have brought into question the representativeness of our data (which contained mostly strategic fund-seekers). Likewise, it would have suggested support for the Pecking Order Theory: that startups using ECF simply do not have access to, or failed in securing, funding from more desirable sources. We found no such indication. Instead, this basic robustness check reinforced the findings of the original data: that there is more to the story than the Pecking Order Theory given the social and legislative changes that have ushered in ECF.

\section{Discussion}

We conducted an inductive study with a unique cohort of fund-seekers and identified several underlying factors that these entrepreneurs considered when seeking funding. Using our emergent conceptual model, we extend the venture funding literature in several ways as described below.

5.1 Adopting a contingency-based model of funding fit to understand venture funding

Theoretically, our model introduces the concept of funding fit: a contingency based perspective which specifies that equity fund-seeking is a dynamic process in which entrepreneurs attempt to identify the funding mode that best fits their particular needs and circumstances at a given point in time. In determining funding fit, we propose that several fund-seeking factors (described in the next section) are actively and explicitly considered as influential factors by entrepreneurs. Although we advocate that fund-seeking should be considered a dynamic, contingency-based process, we do not believe the model that we present here is a fully specified 
model and it is likely that several other contingency factors could play a role in differing fundseeking contexts.

Our model of funding fit is distinct from other fund-seeking models which consider internal funding, debt, and equity (e.g., the pecking order hypothesis; Myers, 1984) —and rule-based transactional models (e.g., Transaction Cost Economics; Williamson, 1979). As Williamson (1998) proposed, when technology and regulation shift (as has occurred recently in the USA venture funding market), theory should adapt and expand to explain novel forms of organizing (such as ECF). Our research indicates that strategic fund-seekers in our cases were discriminant evaluators of different types of equity options, rather than entrepreneurs pursuing ECF because it was the only funding mode they could secure.

Our findings have implications for our understanding of the multistage selection process that entrepreneurs use to consider funding options (cf. Eckhardt et al., 2006), as well as the hurdles that must be overcome to secure funding (Eckhardt and Ciuchta, 2008). In particular, our research reveals that perceived funding fit was reflexive in nature, was idiosyncratic based on the unique circumstances and experiences of each entrepreneur, and was likely to unfold over time. Thus, perceptual funding fit will be conceived differently by different entrepreneurs facing similar circumstances (unlike prior rule-based models of fund seeking, e.g., the pecking order assumption). Ryan Caldbeck, an ECF portal founder summarized a broad interpretation of how funding fit will be perceived by different types of entrepreneurs:

\section{Marketplaces exist to move capital in a more efficient, cheaper way.... In a digital-first world, that means creating a transparent, open process where entrepreneurs can choose which investors to take on when raising funds. For some entrepre- neurs, that will mean finding support from the crowd, while for others it will mean seeking a specific few investors with relevant experience.}

Applying our model of funding fit to the ECF setting, we inductively found that for several strategic fund-seekers ECF was actually a preferred funding source given their perceptions related to several critical factors. However, we caution that ECF is not a silver bullet for all types of entrepreneurs. That is, in line with the theoretical contingency model we develop, ECF should certainly not be perceived as the "right fit" for all entrepreneurs. The conceptual model of funding fit that we present in this research builds on prior work by codifying and unpacking several key factors that entrepreneurs in the modern era consider when fund-seeking, responding to calls to consider an entrepreneur-based view (e.g., Shepherd et al., 2015).

\subsection{The contingency factors considered by strategic fund-seekers}

Power and efficiency considerations First, strategic fund-seekers in our sample were highly motivated to retain contractual power ex-post. Prior research shows that covenants that allow traditional investors to retain power are the norm to offset agency risk (Van Osnabrugge, 2000). For entrepreneurs, avoiding restrictive convents and maintaining long-term strategic control is clearly preferable (Aghion and Bolton, 1992); however the relative imbalance in funding markets prior to the introduction of ECF made this quite difficult for entrepreneurs to achieve. Our work reveals the balance of power might now be shifting. Perhaps this power shift for entrepreneurs will extend beyond the ECF setting. For example, the likelihood of retaining control after a Series A round was negligible in years past (Graham, 2010), but today entrepreneurs who are able to generate a high volume of interest from funders have been able to maintain strategic control all the way to IPO (e.g., Zuckerberg from Facebook and Pincus from Zynga). In addition to retaining strategic control, entrepreneurs in our sample also believed that ECF afforded them several efficiencies relative to other equity sources.

Value capture and value creation considerations $\mathrm{We}$ know from prior research that, in addition to funding, entrepreneurs covet complementary value such as strategic value from investors in the form of management expertise (Baum and Silverman, 2004; Ciuchta et al., 2018; Hellmann and Puri, 2002; Park and Steensma, 2012). However, our data reveals that strategic ECF fund-seekers are willing to forgo the benefits of working with established investors. Rather, strategic ECF fundseekers in our sample preferred to capture demand-side value in the form of mass referrals, prospective customer lists, and social hype generation via ECF. 
Moreover, our data also revealed that entrepreneurs could benefit from a novel form of complementary value created by the dynamic crowd-based process itself. This relatively unstudied form of complementary value, which we refer to as market validation information, provided entrepreneurs with data from a large pool of individuals about potential consumer adoption and decentralized perceptions of product value. Strategic fund-seekers viewed the ECF process as a value creation mechanism in itself. Thus, our findings have important implications for our understanding of the role of complementary value as a motivator for fund-seeking. We expect that as entrepreneurs desire to obtain market validation information increases, they will be more likely to opt for ECF. We extend the literature related to the psychological underpinnings of organizing, particularly scholarship focused on value capture in funding transactions (e.g., Park and Steensma, 2012; Stuart, 2000) and incomplete contracting (Gong et al., 2001). Our results demonstrate how the ECF process creates novel complementary value for entrepreneurs.

External stakeholder values Some entrepreneurs in our sample reasoned that the crowd was more likely to value their "social" or "blended value" mandates, relative to angels or VCs. However, for the most part, strategic fund-seekers in our sample were not driven by the need to create social value. Rather, they were focused on funding effeciency and retaining strategic control. They viewed ECF as a mechanism to achieve these ends.

\subsection{Limitations and opportunities for future research}

There are several opportunities for future research to extend our findings. First, our primary data collection focused on an "initial cohort" of firms. We ran robustness checks to ensure that our sample was representative of the broader population, yet we still expect that future work could greatly enhance the initial efforts we have made toward a model of funding fit. Specifically, future research should extend beyond our sampling frame and study other ECF fund-seekers. Since we relied on qualitative data with a sample of informants and publicly available artifacts, the model we develop may not be fully complete. The artifacts may not reflect all elements of funding fit, and thus future research should consider other contingency factors that influence fit perceptions. Relatedly, future research should consider how recent innovations in equity funding markets (such as the rise of equity crowdfunding or initial coin offerings) alter long-standing transactional, value capture, or rule-based models of fund-seeking, which were largely established before the internet and crowd-based processes were widely available.

Second, our data collection efforts were restricted to one country, the USA. We focused on this market since at the time of our study ECF had just emerged as a novel source of capital (SEC, 2016b), and there were several questions about how its emergence might alter USbased funding markets (Drover et al., 2017; SEC, 2016c). Although focusing on one country could be limiting, this approach is in line with other exemplar qualitative papers (Greenwood and Suddaby, 2006; Khavul et al., 2013). While our study relied on a limited case set, the number of cases was comparable to other entrepreneurship studies (e.g., Grimes, 2010; Williams and Shepherd, 2016). Further research should consider expanding the model of funding fit that we initiate with this research by using other methodologies such as quantitative field studies or experiments.

Finally, although the model we developed in this paper was focused on fund-seeker perceptions of alternative equity sources, we acknowledge that many of the features of ECF (e.g., efficiency, value creation) that might also be considered benefits in other forms of crowdfunding. Future research might explore such generalizability of our findings to such settings (e.g., rewards-based crowdfunding). In the present research, though, the distinction in our theorizing was centered on equity funding forms. Unlike rewards-based crowdfunding, ECF funders own a part of the business, leading them to buy in on a more substantial basis in contrast with rewards-based crowdfunders who may simply fund to receive rewards. The strategic fundseekers in our sample identified this divergence as well. The founder of Organic noted that he was motivated to incorporate his potential customers directly into the business by making them not only a stakeholder but also a shareholder, noting specifically, "we want them to be a shareholder and a stakeholder of everything we do." MedWeb's founder shared this perception, "We've received several unsolicited investment offers from [our users] over the years, and our main objective with this campaign is to finally allow them an opportunity to invest in the company." Relatedly, given that funding fit is specified in our theoretical model as a perception at a given point in time, future research might consider how funding fit changes over time as the venture 
evolves. Longitudinal collections or experimental studies may be particularly suitable to answer this research question.

\section{Conclusion}

We conduct an inductive study of fund-seeking firms to uncover the critical factors which underlie the decision to seek ECF. With these data, we propose a dynamic contingency-based model of perceived funding fit. We find that perceived funding fit motivates some strategic fund-seekers to opt for ECF, even when they have reasonable prospects to obtain other established sources of funding such as angel or seed-stage venture capital, indicating that ECF is not always a funding mode of last resort from the perspective of the fund-seeking entrepreneur. We hope our initial conceptual approach spurs future research on funding fit from the entrepreneur's perspective.

\section{References}

Aghion, P., \& Bolton, P. (1992). An incomplete contracts approach to financial contracting. The Review of Economic Studies, 59(3), 473. https://doi.org/10.2307/2297860.

Ahlers, G. K. C., Cumming, D. J., Guenther, C., Schweizer, D., Günther, C., \& Schweizer, D. (2015). Signaling in equity crowdfunding. Entrepreneurship Theory and Practice, 39(4), 955-980. https://doi.org/10.1111/etap.12157.

Baker, T., \& Nelson, R. E. (2005). Creating something from nothing: resource construction through entrepreneurial bricolage. Administrative Science Quarterly, 50(3), 329-366. https://doi.org/10.2189/asqu.2005.50.3.329.

Bapna, S. (2019). Complementarity of signals in early-stage equity investment decisions: evidence from a randomized field experiment. Management Science, 65(2), 933-952. https://doi. org/10.1287/mnsc.2017.2833.

Barley, S. R. (1986). Technology as an occasion for structuring: evidence from observations of CT scanners and the social order of radiology departments. Administrative Science Quarterly, 31(1), 78-108. https://doi.org/10.2307/2392767.

Bartlett, J. W. (1999). Negotiating the best valuation and terms for early-stage investment. The Journal of Private Equity, 2(3), 7-14. https://doi.org/10.3905/jpe.1999.319949.

Baum, J. A. C. R., \& Silverman, B. S. (2004). Picking winners or building them? Alliance, intellectual, and human capital as selection criteria in venture financing and performance of biotechnology startups. Journal of Business Venturing, 19(3), 411-436. https://doi.org/10.1016/S0883-9026(03 )00038-7.

Bellavitis, C., Filatotchev, I., Kamuriwo, D. S., \& Vanacker, T. (2017). Entrepreneurial finance: new frontiers of research and practice. Venture Capital, 19(1-2), 1-16. https://doi. org/10.1080/13691066.2016.1259733.

Belleflamme, P., Lambert, T., \& Schwienbacher, A. (2014). Crowdfunding: tapping the right crowd. Journal of Business Venturing, 29(5), 585-609. https://doi.org/10.1016 /j.jbusvent.2013.07.003.

Blank, S. (2013). Why the lean start-up changes everything. Harvard Business Review, 5, 63-72.

Blaseg, D., Cumming, D., \& Koetter, M. (2020). Equity crowdfunding: high-quality or low-quality entrepreneurs? Entrepreneurship Theory and Practice. https://doi. org/10.1177/1042258719899427.

Brown, R., Mawson, S., Rowe, A., \& Mason, C. (2018). Working the crowd: improvisational entrepreneurship and equity crowdfunding in nascent entrepreneurial ventures. International Small Business Journal: Researching Entrepreneurship, 36(2), 169-193. https://doi.org/10.1177 $/ 0266242617729743$.

Bruton, G. D., Khavul, S., Siegel, D., \& Wright, M. (2015). New financial alternatives in seeding entrepreneurship: microfinance, crowdfunding, and peer-to-peer innovations. Entrepreneurship Theory and Practice, 39(1), 9-26. https://doi.org/10.1111/etap.12143.

Busenitz, L. W., Fiet, J. O., \& Moesel, D. D. (2005). Signaling in venture capitalist - new venture decisions: does it indicate venture outcomes? Entrepreneurship Theory and Practice, 29(1), 1-12. https://doi.org/10.1111/j.15406520.2005.00066.x.

Camerer, C. F., Loewenstein, G., \& Rabin, M. (2004). Behavioral economics: past, present, future. In Advances in behavioral economics. Princeton: Princeton University Press.

Casson, M. (1982). The entrepreneur: an economic theory. Rowman and Littlefield Publishing Group.

Cholakova, M., \& Clarysse, B. (2015). Does the possibility to make equity investments in crowdfunding projects crowd out reward-based investments? Entrepreneurship Theory and Practice, 39(1), 145-172. https://doi.org/10.1111 /etap. 12139.

Ciuchta, M. P., Letwin, C., Stevenson, R., McMahon, S., \& Huvaj, M. N. (2018). Betting on the coachable entrepreneur: signaling and social exchange in entrepreneurial pitches. Entrepreneurship Theory and Practice, 42(6), 860-885. https://doi.org/10.1177/1042258717725520.

Cumming, D., Meoli, M., \& Vismara, S. (2019). Investors' choices between cash and voting rights: evidence from dual-class equity crowdfunding. Research Policy, 48(8), 103740. https://doi.org/10.1016/j.respol.2019.01.014.

Cummings, M. E., Rawhouser, H., Vismara, S., \& Hamilton, E. L. (2020). An equity crowdfunding research agenda: evidence from stakeholder participation in the rulemaking process. Small Business Economics, 54(4), 907-932. https://doi. org/10.1007/s11187-018-00134-5.

Cyert, R. M., \& March, J. G. (1963). A behavioral theory of the firm. Englewood Cliffs. https://doi.org/10.1080 /00137916408928711.

David, R. J., Sine, W. D., \& Haveman, H. A. (2013). Seizing opportunity in emerging fields: how institutional entrepreneurs legitimated the professional form of management consulting. Organization Science, 24(2), 356-377. https://doi. org/10.1287/orsc. 1120.0745 . 
Drover, W., Busenitz, L. W., Matusik, S., Townsend, D., Anglin, A. H., \& Dushnitsky, G. (2017). A review and road map of entrepreneurial equity financing research: venture capital, corporate venture capital, angel investment, crowdfunding, and accelerators. Journal of Management, 43(6), 1820-1853. https://doi.org/10.1177/0149206317690584.

Eckhardt, J. T., \& Ciuchta, M. P. (2008). Selected variation: the population-level implications of multistage selection in entrepreneurship. Strategic Entrepreneurship Journal, 2(3), 209-224. https://doi.org/10.1002/sej.

Eckhardt, J. T., Shane, S., \& Delmar, F. (2006). Multistage selection and the financing of new ventures. Management Science, 52(2), 220-232. https://doi.org/10.1287/mnsc.1050.0478.

Eisenhardt, K. M. (1989). Building theories from case study research. The Academy of Management Review, 14(4), 532-550. https://doi.org/10.5465/amr.1989.4308385.

Eisenhardt, K. M., \& Graebner, M. E. (2007). Theory building from cases: opportunities and challenges. The Academy of Management Journal, 50(1), 25-32. https://doi.org/10.5465 /amj.2007.24160888.

Estrin, S., Gozman, D., \& Khavul, S. (2018). The evolution and adoption of equity crowdfunding: entrepreneur and investor entry into a new market. Small Business Economics, 51(2), 425-439. https://doi.org/10.1007/s11187-018-0009-5.

Fisher, G., Stevenson, R., Neubert, E., Burnell, D., \& Kuratko, D. F. (2020). Entrepreneurial hustle: navigating uncertainty and enrolling venture stakeholders through urgent and unorthodox action. Journal of Management Studies, 57(5), 10021036. https://doi.org/10.1111/joms.12584.

Fitza, M. A., Matusik, S. F., \& Mosakowski, E. (2009). Do VCs matter? The importance of owners on performance variance in start-up firms. Strategic Management Journal, 30(4), 387404. https://doi.org/10.1002/smj.748.

Florida, R., \& Mellander, C. (2016). Rise of the global startup city. California Management Review, 59(1), 14-39.

Florin, J. (2005). Is venture capital worth it? Effects on firm performance and founder returns. Journal of Business Venturing, 20, 113-135. https://doi.org/10.1016/j. jbusvent.2003.12.006.

Gehman, J., \& Grimes, M. G. (2017). Hidden badge of honor: how contextual distinctiveness affects category promotion among certified B corporations. The Academy of Management Journal Advanced Online Publication.

Gioia, D. A., Corley, K. G., \& Hamilton, A. L. (2013). Seeking qualitative rigor in inductive research. Organizational Research Methods, 16(1), 15-31. https://doi.org/10.1177 /1094428112452151.

Gleasure, R. (2015). Resistance to crowdfunding among entrepreneurs: an impression management perspective. The Journal of Strategic Information Systems, 24(4), 219-233. https://doi. org/10.1016/j.jsis.2015.09.001.

Gompers, P. A., \& Lerner, J. (2004). The venture capital cycle. Cambridge: MIT Press.

Gong, Y., Shenkar, O., Luo, Y., \& Mee-Kau, N. (2001). Role conflict and ambiguity of CEOs in international joint ventures: a transaction cost perspective. The Journal of Applied Psychology, 86(4), 764-773. https://doi.org/10.1037//00219010.86.4.764.

Graham, P. (2010). Founder Control. http://www.paulgraham. com/control.html
Greenwood, R., \& Suddaby, R. (2006). Institutional entrepreneurship in mature fields: the big five accounting firms. The Academy of Management Journal, 49(1), 27-48. https://doi. org/10.5465/AMJ.2006.20785498.

Grimes, M. G. (2010). Strategic sensemaking within funding relationships: the effects of performance measurement on organizational identity in the social sector. Entrepreneurship Theory and Practice, 34(4), 763-783. https://doi.org/10.1111/j.1540-6520.2010.00398.x.

Hallen, B. L. (2008). The causes and consequences of the initial network positions of new organizations: from whom do entrepreneurs receive investments? Administrative Science Quarterly, 53(4), 685-718. https://doi.org/10.2189 /asqu.53.4.685.

Hallen, B. L., \& Eisenhardt, K. M. (2012). Catalyzing strategies and efficient tie formation: how entrepreneurial firms obtain investment ties. The Academy of Management Journal, 55(1), 35-70. https://doi.org/10.5465/amj.2009.0620.

Hallen, B. L., \& Pahnke, E. C. (2016). When do entrepreneurs accurately evaluate venture capital firms track records? A bounded rationality perspective. The Academy of Management Journal, 59(5), 1535-1560. https://doi. org/10.5465/amj.2013.0316.

Haveman, H. A., \& Baum, J. A. C. (1997). Love thy neighbor? Differentiation and agglomeration in the Manhattan hotel industry. Administrative Science Quarterly, 42(2), 304-338. https://doi.org/10.2307/2393922.

Hellmann, T. F., \& Puri, M. (2002). Venture capital and the professionalization of start-up firms: empirical evidence. The Journal of Finance, LVII(1), 169-197. https://doi. org/10.1111/1540-6261.00419.

Hellmann, T. F., \& Thiele, V. (2015). Friends or foes? The interrelationship between angel and venture capital markets. Journal of Financial Economics, 115(3), 639-653. https://doi.org/10.1016/j.jfineco.2014.10.009.

Hsu, D. H. (2004). What do entrepreneurs pay for venture capital affiliation ? The Journal of Finance, 59(4), 1805-1844. https://doi.org/10.1111/j.1540-6261.2004.00680.x.

Hsu, D. H. (2007). Experienced entrepreneurial founders, organizational capital, and venture capital funding. Research Policy, 36(5), 722-741. https://doi.org/10.1016/j. respol.2007.02.022.

Huy, Q. N., Corley, K. G., \& Kraatz, M. S. (2014). From support to mutiny: Shifting legitimacy judgments and emotional reactions impacting the implementation of radical change. The Academy of Management Journal, 57(6), 1650-1680. https://doi.org/10.5465/amj.2012.0074.

Khanin, D., Baum, J. R., Turel, O., \& Mahto, R. V. (2009). Are some venture capitalists more likely than others to replace founder-CEOs? The Journal of Private Equity, 12(2), 19-29. https://doi.org/10.3905/JPE.2009.12.2.019.

Khavul, S., Chavez, H., \& Bruton, G. D. (2013). When institutional change outruns the change agent: the contested terrain of entrepreneurial micro finance for those in poverty. Journal of Business Venturing, 28(1), 30-50. https://doi.org/10.1016 /j.jbusvent.2012.02.005.

Kirzner, I. M. (1997). Entrepreneurial discovery and the competitive market process: an Austrian approach. Journal of Economic Literature, 35(1), 60-85. https://doi.org/10.2307 12729693 . 
Klonowski, D. (2007). The venture capital investment process in emerging markets: evidence from central and eastern europe. International Journal of Emerging Markets, 2(4), 361-382.

Koss, A. M. (2007). Best practice guidance for angel groups: Deal structure and negotiation. Angel Capital Education Foundation. New York: Angel Resources Institute.

Lehner, O. M. (2013). Crowdfunding social ventures: a model and research agenda. Venture Capital, 15(4), 289-311. https://doi.org/10.1080/13691066.2013.782624.

Lincoln, Y. S., \& Guba, E. G. (1985). Naturalistic inquiry. Newbury Park: Sage.

Maxwell, A. L., Jeffrey, S. A., \& Lévesque, M. (2011). Business angel early stage decision making. Journal of Business Venturing, 26(2), 212-225. https://doi.org/10.1016/j. jbusvent.2009.09.002.

McMullen, J. S., \& Warnick, B. J. (2016). Should we require every new venture to be a hybrid organization? Journal of Management Studies, 53(4), 630-662. https://doi. org/10.1111/joms.12150.

Mises, L. V. (1949). Human action. New Haven: Yale University Press.

Myers, S. C. (1984). The capital structure puzzle. The Journal of Finance, 39(3), 575-592.

Nelson, T. (2003). The persistence of founder influence: management, ownership, and performance effects at initial public offering. Strategic Management Journal, 24(8), 707-724. https://doi.org/10.1002/smj.328.

Nicholson, L. H. (2003). A Hobson's choice for securities lawyers in the post-Enron environment: striking a balance between the obligation of client loyalty and market gatekeeper. Georgetown Journal of Legal Ethics, 16(91), 91-154.

Park, H. D., \& Steensma, H. K. (2012). When does corporate venture capital add value for new ventures? Strategic Management Journal, 33(1), 1-22. https://doi.org/10.1002 /smj.937.

PitchBook Data. (2016). Annual VC valuations report. New York.

Powell, T. C., Lovallo, D., \& Fox, C. R. (2011). Behavioral strategy. Strategic Management Journal, 32, 1369-1386. https://doi.org/10.1002/smj.

Pratt, M. G. (2000). The good, the bad, and the ambivalent: managing identification among amway distributors. Administrative Science Quarterly, 45(3), 456. https://doi. org/10.2307/2667106.

PWC. (2017). Money tree report. Price Waterhouse Coopers National Venture Capital Association Report.

Rosenstein, J. (1988). The board and strategy: venture capital and high technology. Journal of Business Venturing, 3, 159-170. https://doi.org/10.1016/0883-9026(88)90024-9.

Sapienza, H. J., Manigart, S., \& Vermeir, W. (1996). Venture capitalist governance and value added in four countries. Journal of Business Venturing, 11(6), 439-469. https://doi. org/10.1016/S0883-9026(96)00052-3.

SEC. (2016a). Regulation Crowdfunding: a small entity compliance guide for issuers. Ww w. sec. gov/info/smallbus/secg/rccomplianceguide-051316.htm

SEC. (2016b). RIN 3235-AL37: Crowdfunding Final Rules. 17 CFR Parts 200, 227, 232, 239, 240 and 249. https://www. sec.gov/rules/final/2015/33-9974.pdf

SEC. (2016c). Investor bulletin: crowdfunding for investors. https://www.sec.gov/oiea/investor-alerts-bulletin
SEC. (2017). Form C. United States. https://www.sec. gov/files/formc.pdf

Shane, S. (2009). Why encouraging more people to become entrepreneurs is bad public policy. Small Business Economics, 33(2), 141-149. https://doi.org/10.1007/s11187-009-9215-5.

Shankar, R. K., \& Shepherd, D. A. (2018). Accelerating strategic fit or venture emergence: different paths adopted by corporate accelerators. Journal of Business Venturing, 2017, 1-19. https://doi.org/10.1016/j.jbusvent.2018.06.004.

Sharma, G., \& Good, D. J. (2013). The work of middle managers: sensemaking and sensegiving for creating positive social change. The Journal of Applied Behavioral Science, 49(1), 95-122 http://apps.webofknowledge.com/full_record. do?product=UA\&search_mode $=$ MarkedList\&qid $=11$

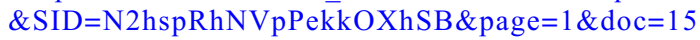
$\& \operatorname{colName}=$ W O S \% $5 \mathrm{Cnhttp}: / /$ jab.sagepub. com/cgi/doi/10.1177/0021886312471375.

Shepherd, D. A., Williams, T. A., \& Patzelt, H. (2015). Thinking about entrepreneurial decision making: review and research agenda. Journal of Management, 41(1), 11-46 http://jom. sagepub.com/cgi/doi/10.1177/0149206314541153.

Sohl, J. (2016). The angel investor market in 2015. Center for Venture Research. http://paulcollege.unh.edu/center-ventureresearch

Sonenshein, S., Nault, K., \& Obodaru, O. (2017). Competition of a different flavor: how a strategic group identity shapes competition and cooperation. Administrative Science Quarterly, 62(4), 626-656. https://doi.org/10.1177 /0001839217704849.

Sorensen, M. (2007). How smart is smart money? A two-sided matching model of venture capital. The Journal of Finance, 62(6), 2725-2762.

Stevenson, R., Ciuchta, M. P., Letwin, C., Dinger, J. M., \& Vancouver, J. B. (2019a). Out of control or right on the money? Funder self-efficacy and crowd bias in equity crowdfunding. Journal of Business Venturing, 34(2), 348367. https://doi.org/10.1016/j.jbusvent.2018.05.006.

Stevenson, R., Kuratko, D. F., \& Eutsler, J. (2019b). Unleashing main street entrepreneurship: crowdfunding, venture capital, and the democratization of new venture investments. Small Business Economics, 52(2), 375-393. https://doi. org/10.1007/s11187-018-0097-2.

Straus, A., \& Corbin, J. (1990). Basics of qualitative research: grounded theory procedures and techniques. Thousand Oaks: Sage Publications, Inc..

Strauss, A., \& Corbin, J. (1998). Basics of qualitative research: techniques and procedures for developing grounded theory (2nd ed.). Newbury Park: Sage.

Stuart, T. E. (2000). Interorganizational alliances and the performance of firms: a study of growth and innovation rates in a high-technology industry. Strategic Management Journal, 21(8), 791-811.

Van Osnabrugge, M. (2000). A comparison of business angel and venture capitalist investment procedures: an agency theorybased analysis. Venture Capital, 2(2), 37-41.

Vismara, S. (2016). Equity retention and social network theory in equity crowdfunding. Small Business Economics, 46(4), 579-590. https://doi.org/10.1007/s11187-016-9710-4.

Waldron, T. L., Fisher, G., \& Navis, C. (2015). Institutional entrepreneurs' social mobility in organizational fields. 
Journal of Business Venturing, 30(1), 131-149. https://doi. org/10.1016/j.jbusvent.2014.06.006.

Walthoff-Borm, X., Schwienbacher, A., \& Vanacker, T. (2018a). Equity crowdfunding: first resort or last resort? Journal of Business Venturing, 33(4), 513-533. https://doi.org/10.1016 /j.jbusvent.2018.04.001.

Walthoff-Borm, X., Vanacker, T., \& Collewaert, V. (2018b). Equity crowdfunding, shareholder structures, and firm performance. Corporate Governance: An International Review, 26(5), 314-330. https://doi.org/10.1111/corg.12259.

Wasserman, N. (2008). The founder's dilemma. Harvard Business Review, Harvared B, 1-8.

Welter, F., Baker, T., Audretsch, D. B., \& Gartner, W. B. (2017). Everyday entrepreneurship - a call for entrepreneurship research to embrace entrepreneurial diversity. Entrepreneurship Theory and Practice, 41(3), 311-321.

Williams, T. A., \& Shepherd, D. A. (2016). Building resilience or providing sustenance: different paths of emergent ventures in the aftermath of the Haiti earthquake. The Academy of Management Journal, 59(6), amj.2015.0682.

Williamson, O. E. (1979). Transaction-cost economics: the governance of contractual relations. Journal of Law and Economics, 22, 233-261.
Williamson, O. E. (1988). Corporate finance and corporate governance. The Journal of Finance, 43(3), 567-591. https://doi. org/10.1111/j.1540-6261.1988.tb04592.x.

Williamson, O. E. (1998). Transaction cost economics: how it works; where it is headed. De Economist, 146(1), 23-58. https://doi.org/10.1023/A:1003263908567.

Wry, T., \& York, J. G. (2015). An identity based approach to social enterprise. The Academy of Management Review, in press. https://doi.org/10.5465/amr.2013.0506.

York, J. L., \& Danes, J. E. (2014). Customer development, innovation, and decision-making biases in the Lean Startup. Journal of Small Business Strategy, 24(2), 21-39.

Zacharakis, A. L., Erikson, T., \& George, B. (2010). Conflict between the VC and entrepreneur: the entrepreneur's perspective. Venture Capital, 12(2), 109-126. https://doi. org/10.1080/13691061003771663.

Zott, C., \& Huy, Q. N. (2007). How entrepreneurs use symbolic management to acquire resources. Administrative Science Quarterly, 52(1), 70-105. https://doi.org/10.2189 /asqu.52.1.70.

Publisher's note Springer Nature remains neutral with regard to jurisdictional claims in published maps and institutional affiliations. 